\title{
Coarse Coal Hydrotransport Studies Using the Separate Effects Test Stand: FY 1980-1981
}

T. B. Powers

September 1981

Prepared for the U.S. Department of Energy under Contract DE-AC06-76RLO 1830

Pacific Northwest Laboratory Operated for the U.S. Department of Energy by Battelle Memorial Institute 


\title{
NOTICE
}

This report was prepared as an account of work sponsored by the United States Government. Neither the United States nor the Department of Energy, nor any of their employees, nor any of their contractors, subcontractors, or their employees, makes any warranty, express or implied, or assumes any legal liability or responsibility for the accuracy, completeness or usefulness of any information, apparatus, product or process disclosed, or represents that its use would not infringe privately owned rights.

The views, opinions and conclusions contained in this report are those of the contractor and do not necessarily represent those of the United States Government or the United States Department of Energy.

\author{
PACIFIC NORTHWEST LABORATORY \\ operated by \\ BATTELLE \\ for the \\ UNITED STATES DEPARTMENT OF ENERGY \\ Under Contract DE-AC06-76RLO 1830
}

\author{
Printed in the United States of America \\ Available from \\ National Technical Information Service \\ United States Department of Commerce \\ 5285 Port Royal Road \\ Springfield, Virginia 22151 \\ Price: Printed Copy $\mathbf{S}$ \\ $\because$ Microfiche $\$ 3.00$

\begin{tabular}{c|c} 
•Pages & $\begin{array}{c}\text { NTIS } \\
\text { Selling Price }\end{array}$ \\
\hline $001-025$ & $\$ 4.00$ \\
$026-050$ & $\$ 4.50$ \\
$051-075$ & $\$ 5.25$ \\
$076-100$ & $\$ 6.00$ \\
$101-125$ & $\$ 6.50$ \\
$126-150$ & $\$ 7.25$ \\
$151-175$ & $\$ 8.00$ \\
$176-200$ & $\$ 9.00$ \\
$201-225$ & $\$ 9.25$ \\
$226-250$ & $\$ 9.50$ \\
$251-275$ & $\$ 10.75$ \\
$276-300$ & $\$ 11.00$
\end{tabular}


COARSE COAL HYDROTRANSPORT STUDIES USING THE SEPARATE EFFECTS TEST STAND: FY 1980-1981

T. B. Powers

September 1981

Prepared for

the U.S. Department of Energy under Contract DE-AC06-76RLO 1830

Pacific Northwest Laboratory Richland, Washington 99352 


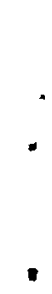


SUMMARY

The Separate Effects Test Stand (SETS) was built to evaluate the rotating pipe-wheel stand concept for hydrotransport testing and to obtain hydrotransport data in support of the U.S. Department of Energy's Hydraulic Transport Research Facility (HTRF). The SETS program involved three phases of testing. The first phase was to evaluate the wheel test stand as an adequate mechanism for testing the hydrotransport of coarse-particle coal through pipe. The second phase was to obtain preliminary data on coal head loss (flow pressure drop) during hydrotransport. The third phase was to determine the effects of coal hydrotransport on water quality. Other data obtained during the program included pipe wear and the size degradation of coal particles.

The SETS was tested with water only and the resultant head loss data were compared with head loss values recorded for water flow in straight pipe. These tests were run to determine how well the SETS modeled straight pipe flow. Preliminary data on head loss for coal hydrotransport were obtained using a locally obtained western coal in contrast to the Pittsburgh Seam coal used in the HTRF. The final results of the water-only tests and the local coal tests are still being analyzed and will be reported in a supplemental report. The effects of coal hydrotransport on water quality were determined by running a matrix of tests with Pittsburgh Seam coal (and refuse) and then analyzing the resulting mixture.

This report presents the FY 1980-1981 results of the continuing SETS program conducted by the Pacific Northwest Laboratory for the Department of Energy.

The conclusions reached in this report for FY 1981 are related to the water-only tests, the local coal tests, and the water quality tests: Water-Only Tests

- The 6-in./13.45-ft (pipe diameter/wheel diameter) ring was chosen to be used for all the local coal tests and water quality tests. 


\section{Local Coal Tests}

- Fines smaller than 5 mesh increase linearly with increasing concentration of coal in water for test times less than 1-1/4 hours.

Water Quality Tests

- Certain coal and refuse tests generated a stable foam.

- Because the concentration of suspended solids is high, their removal is necessary before water can be discharged to a sewer.

- Dissolved Organic Carbon (DOC), Chemical Oxygen Demand (COD), iron, and arsenic appear to be potential problems with respect to dissolved constituents in the water as related to wastewater disposal.

- Head loss increases when the stable foam is generated and continues to increase as the consistency of the foam increases.

- Refuse tested in conjunction with coal significantly increases the size degradation of coal particles when compared to "coal-only" tests.

- Measurable pipe wear was determined by ultrasonic and weighing methods.

In order to satisfactorily complete the past work, the following recommendations are made for work to be done in FY 1982:

- Additional testing and analysis of water-only and coal head loss data are necessary to accurately explain the reasons for head loss trends.

- Additional work is necessary to characterize the stable foam that was generated and to determine how the foam generation can be either inhibited or counteracted.

- The best methods for treating the waste water before discharge from a facility should be determined. 
- Additional pipe wear testing to examine the effects of various parameters; such as type of coal, amount of refuse, duration, etc.; is also recommended, but limitations in the FY 1982 budget preclude this. 


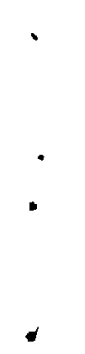




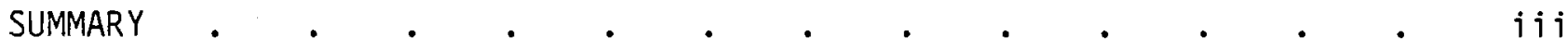

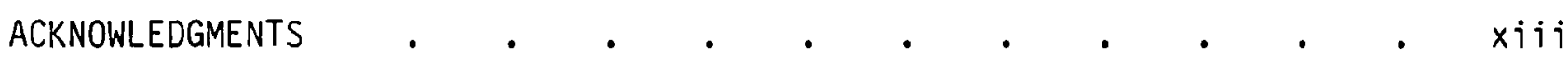

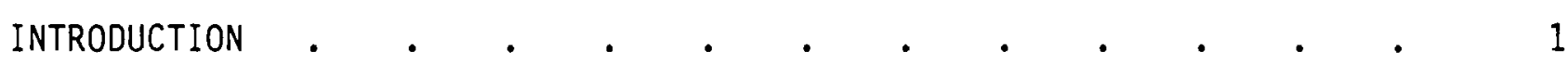

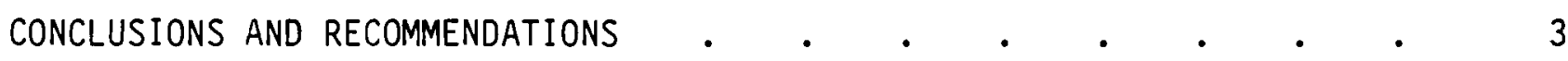

THEORETICAL JUSTIFICATION FOR SETS •

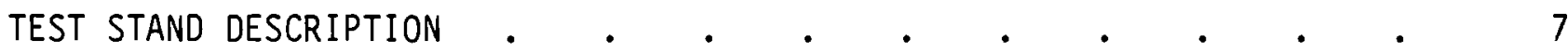

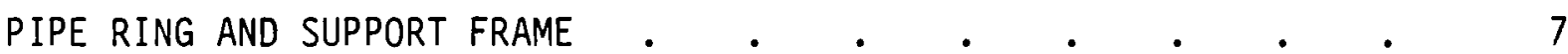

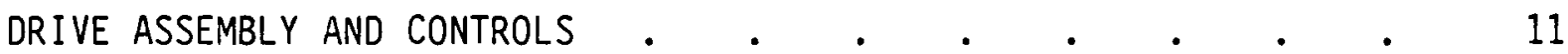

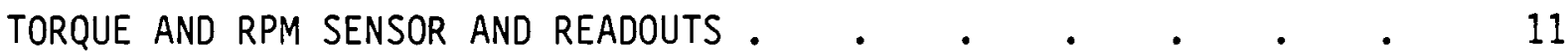

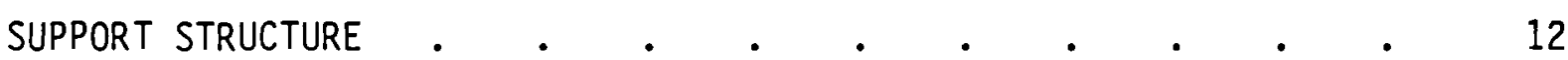

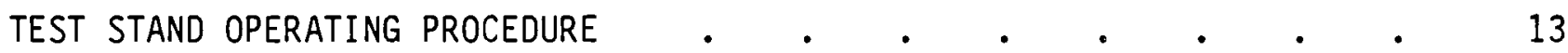

MOUNTING PIPE RING AND SUPPORT FRAME $\quad . \quad \ldots \quad . \quad . \quad . \quad$. 13

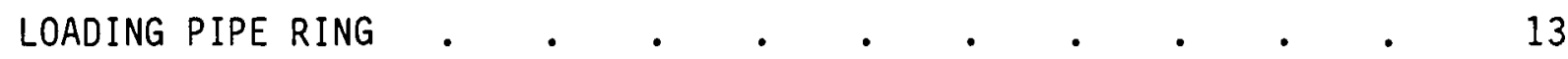

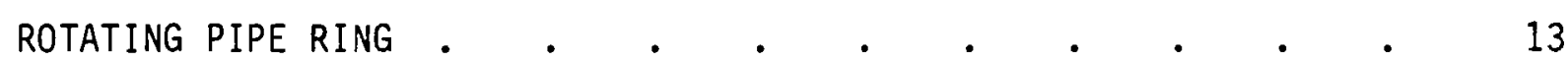

EMPTYING PIPE RING • $\quad$ • $\quad$ • $\quad$ • $\quad$ •

PRELIMINARY WATER TESTS

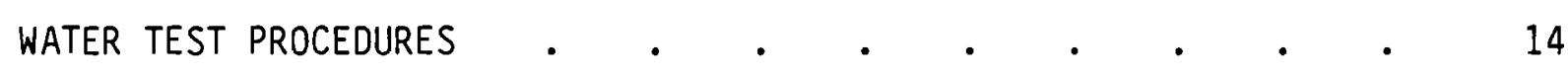

HEAD LOSS RESULTS

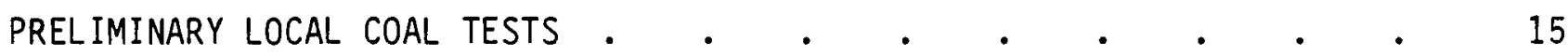

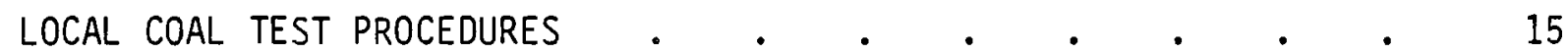

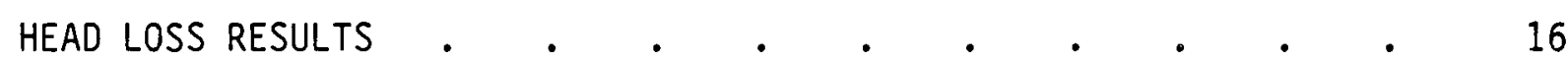

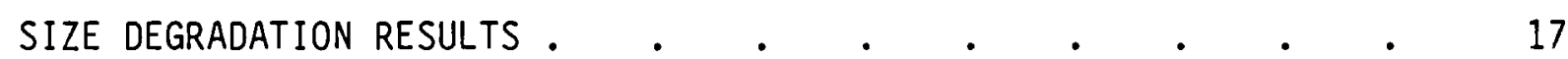

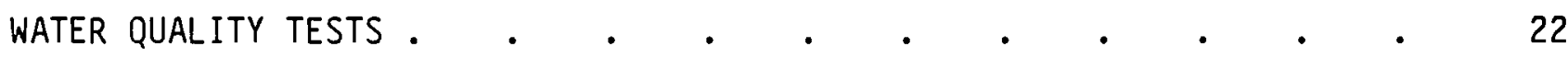

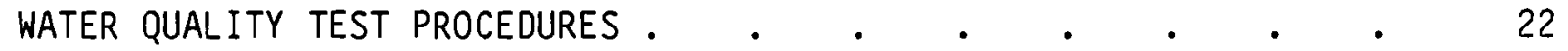




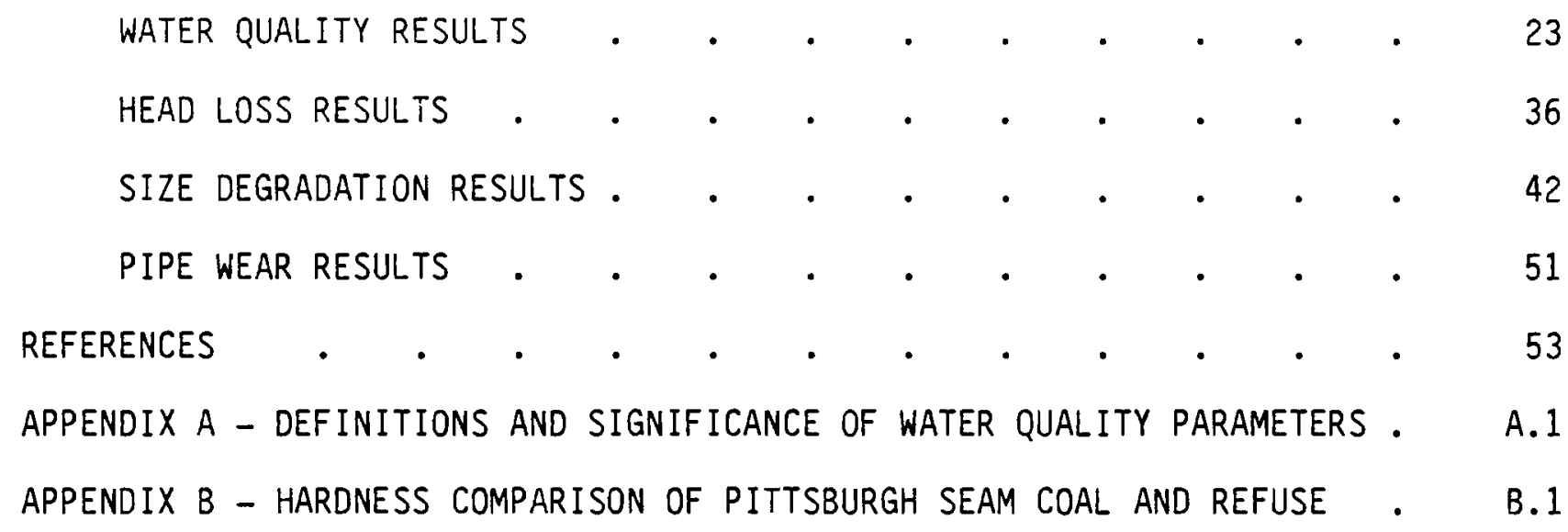




\section{FIGURES}

1 Illustration of Head Developed in Test Pipe Ring . . . . 6

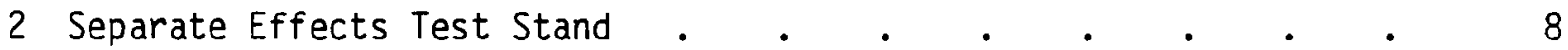

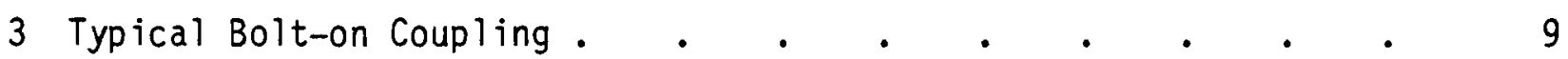

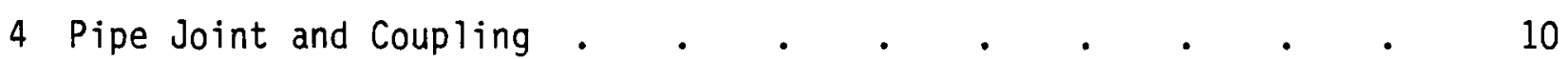

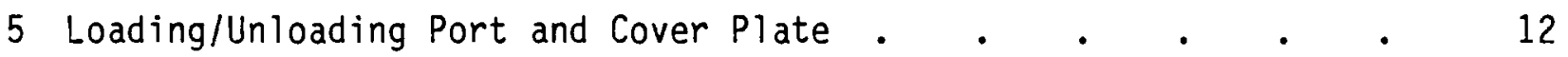

6 Local Coal Size Degradation for Tests 1, 2, and 3. . . . 18

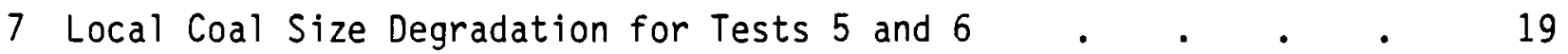

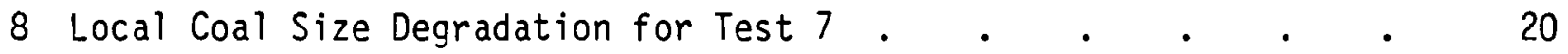

9 Local Coal Size Degradation for Tests 19, 20, $21 \quad$. $\quad$. $\quad$. 21

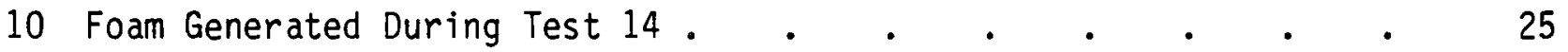

11 Foam Generated During Test 24 . . . . . . . . . 26

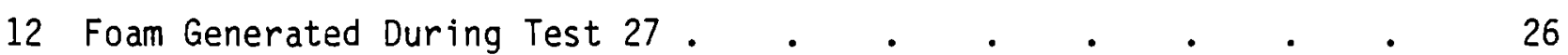

13 Foam Generated During Test 28 . 27

14 Head Loss vs Time During Coal-Only Test . . . . . . 37

15 Head Loss vs Time During Coal and Refuse Test . $\quad$ • $\quad$. 38

16 Head Loss vs Time During a Foam Generation Test . $\quad$ • . . 39

17 Coal Before and After Testing . . . . . . . . . 40

18 Refuse Before and After Testing . . . . . . . . . . 41

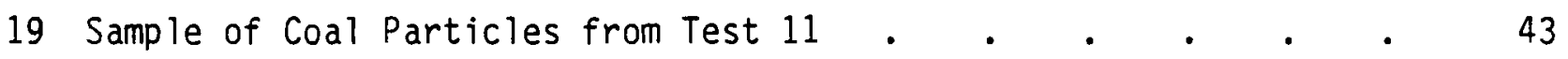

20 Size Degradation for Water Quality Tests 10 and $11 \quad$ • $\quad$ • $\quad 44$

21 Size Degradation for Water Quality Tests 11 and $12 \quad$ • $\quad$ • $\quad$ - 45

22 Size Degradation for Water Quality Tests 12 and 13 - Coal • . 46

23 Size Degradation for Water Quality Tests 12 and 13 - Refuse . . 48 
24 Size Degradation for Water Quality Tests 13 and 23 - Coal . . 49

25 Size Degradation for Water Quality Tests 13 and 23 - Refuse . . 50

B.1 Graph Showing Absolute Hardness of the Moh Minerals . . . . B.3 


\section{TABLES}

1 Local Coal Tests Run with 6-in./13.45-ft Ring . . . . . 16

2 Local Coal Tests Run with 6-in./6.41-ft Ring . . . . . 16

3 Water Quality Tests . . . . . . . . . . . . . . 24

4 Analytical Water Quality Data. . . . . . . . . . . . 29

5 Dissolved Heavy Metal Concentrations in Sample 14-B . . . 32

6 Effect of Coal on the Quality of Raw Water . . . . . . 33

7 Effect of Refuse on Water Quality When Tested with Coal . . 34

8 Effect of Initial Average Size Particles of Coal and Refuse on

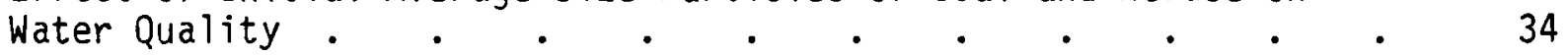

9 Effect of Concentration of Solids on Water Quality . . . . 35

10 Effect of the Time of Contact of Solids in Water on Water Quality . . . . . . . . . . . . 35

11 Sieve Analysis of Test Sample 23-B . . . . . . . . . . 51 


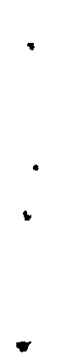




\section{ACKNOWLEDGMENTS}

This work was performed under the direction of Anthony J. Miscoe of the Department of Energy, Pittsburgh Mining Technology Center. I would like to express my appreciation to Charlie Allen, Gordon Dudder, Walt Enderlin, George Lyon, Marv Mason, Basil Mercer, Mike Morgenstern, and Earl Schwenk for their assistance with this project; Leonard Shotwell for his conscientious operation of the SETS apparatus; Steve Matsumoto for his editing assistance; and Jackie Richelieu for her typing assistance, all of Pacific Northwest Laboratory (PNL). I would like to give a special thanks to Pete Riegel of Battelle Columbus for his help in obtaining the Pittsburgh Seam coal used for testing. 


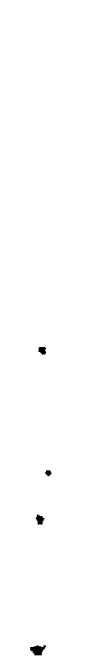




\section{INTRODUCTION}

The U.S. Department of Energy (DOE) is promoting technology developments in coal mining. One development being examined by DOE is the hydrotransport method of conveying coarse raw coal from underground mines to the surface. The development of this method requires obtaining more data on hydrotransport of coarse raw coal. The amount of available data on coarse coal hydrotransport is small as compared to the large amount of data currently available on fine clean coal slurry transport. The Department of Energy has built the Hydraulic Transport Research Facility (HTRF) to obtain data for use in designing and operating a full-scale hydraulic mine transport system.

The Separate Effects Test Stand (SETS) is a DOE project established to support the HTRF. The experimental work in this project is done on a wheel test stand. The SETS is a wheel test stand that consists of a supported ring of pipe that is partially filled with solids and liquid and rotated in a vertical plane around a stationary horizontal axis. Its motion allows for the simulation of fluid flow within the pipe. The test stand is called the Separate Effects Test Stand because the effects of various hydrotransport parameters can be examined separately. The SETS is more economical than a large pumped-loop system because comparatively small amounts of solids and liquid are needed to run an individual test. Since there is no pump in the SETS system, various parameters of interest are not influenced by the pump's operation. The objective of the SETS test program is to obtain coarse coal hydrotransport data related to head loss, particle size degradation, water quality, and pipe wear.

The SETS research program originated in response to the DOE's interest in the Russian work that was reported in Parameters and Regimes of Hydraulic Transportation of Coal by Pipelines (Trainis 1970) and an earlier English work reported by Worster and Denny (1955). The research described in the Russian and English references was accomplished with a wheel stand hydrotransport apparatus. Based on the interest expressed by DOE, a wheel stand was designed and installed at PNL. 
The original scope of the SETS research program was to validate the SETS apparatus for use in obtaining hydrotransport data. The SETS apparatus was validated by running water-only tests and comparing head loss data with similar data obtained for water flow in straight pipe. Later the SETS research program became oriented toward providing supplemental information for DOE's Hydraulic Transport Research Facility, calling for coal-water data related to head loss, particle size degradation, and pipe wear. In FY 1980 the research program was revised to consider water quality changes associated with coal hydrotransport.

The following topics are discussed in the subsequent sections:

- Conclusions and Recommendations

- Theoretical Justification for SETS

- Test Stand Description

- Test Stand Operating Procedures

- Preliminary Water Tests

- Preliminary Local Coal Tests

- Water Quality Tests

The work presented in this report was performed at the Pacific Northwest Laboratory (PNL). PNL is operated for DOE by the Battelle Memorial Institute. 
CONCLUSIONS AND RECOMMENDATIONS

The conclusions of this report are related primarily to SETS results obtained in FY 1981 and are arranged as they relate to the water-only tests, the local coal tests, and the water quality tests.

Water-Only Tests

- Of the seven different size of pipe rings tested with water only, the 6-in./13.45-ft (pipe diameter/wheel diameter) ring was selected to be used for the local coal tests and water quality tests.

Local Coal Tests

- Coal particle size degradation was correlated to the amount of coal fines smaller than 5 mesh generated during a test. Fines smaller than 5 mesh increased linearly with increasing concentration of coal in water for test times of less than 1-1/4 hours.

Water Quality Tests

- A stable foam was generated during certain coal and refuse tests. This foam affected the head loss, particle size degradation, and water quality results.

- Head loss increased when stable foam was generated and continued to increase as the consistency of the foam increased.

- The concentration of suspended solids at the end of most of the water quality tests was over $100 \mathrm{~g} / l$. This high concentration indicates that suspended solids removal will be necessary before coal hydrotransport wastewaters can be discharged to a sewer system based on presentiy known regulations.

- Dissolved Organic Carbon (DOC), Chemical Oxygen Demand (COD), iron, and arsenic appear to be potential problems with respect to dissolved constituents in the water as related to wastewater disposal based on presently known regulations. 
- Refuse tested in conjunction with coal significantly increased the amount of size degradation of the coal particles when compared to "coal-only" tests. The amount of coal particle size degradation increased because the refuse was slightly harder than the coal and, thus, the collisions of coal and refuse resulted in more particle size degradation than collisions of coal and other coal particles.

- Measurable pipe wear was determined by ultrasonic and weighing methods. Based on certain assumptions, the pipe wear measurements obtained by the two methods correlate well.

The following are recommendations for future work based primarily on the FY 1981 tests. It is recognized that additional pipe wear testing is necessary to adequately characterize pipe wear caused by coarse coal hydrotransport, but because of limitations in FY 1982 SETS funding, only the following areas of future work are recommended:

- Additional testing and analysis of water-only and coal head loss data are necessary to accurately explain the reasons for certain head loss trends.

- Additional work is necessary to characterize the stable foam that was generated and to determine how the foam generation can be either inhibited or counteracted.

- The best methods for treating the wastewater before discharge from a facility should be determined.

\section{THEORETICAL JUSTIFICATION FOR SETS}

The reason a wheel stand may be used to model fluid flow in straight pipe is because of the dynamic similarity of relative motion at the interface between the fluid and the pipe wall. Thus, in normal hydrotransport, the solid-liquid mixture moves through a stationary pipe whereas in a wheel stand the pipe moves past a relatively stationary solid-liquid mixture. The action that takes place at this interface is largely controlled by the relative motion of the fluid and the pipe wall, not the component of system that is in motion. 
Head loss data are obtained with the SETS apparatus by measuring the torque necessary to rotate the pipe ring. Actually, two different torque measurements are necessary to calculate the head loss due to fluid drag in the pipe ring. The first torque measurement $\left(T_{d}\right)$ is with a dry pipe ring. This is the torque necessary to rotate the pipe ring while overcoming inertia, bearing friction, air friction, and any imbalance in the system. The second torque measurement $\left(T_{W}\right)$ is with a pipe ring partially filled with a liquid or a liquid-solid mixture. This is the torque necessary to rotate the pipe ring

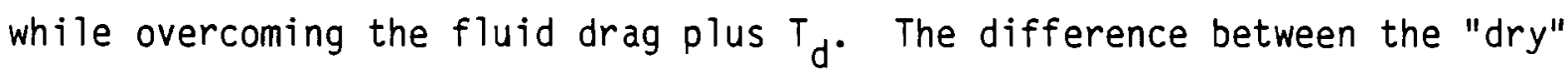
torque $\left(T_{d}\right)$ and the "wet" torque $\left(T_{w}\right)$ is the torque $(T)$ necessary to overcome the fluid drag. Since fluid drag can be expressed as head loss and since fluid drag can be measured as a torque value on the SETS apparatus, then torque can be related to head loss.

The following is a discussion of how head loss, in terms of feet of water per foot of pipe, is calculated using the torque measurement of fluid drag. For clarification refer to Figure 1 which shows the head developed in the test pipe ring. At a constant rotational speed of the pipe ring, a head or height of fluid $(H)$ exists above the height of the fluid level at rest. This head $(H)$ is equal in weight to the drag force tending to cause the fluid to rise in the pipe. The torque $(T)$ is a measure of the weight of fluid head $(H)$ times the moment arm of the pipe ring (radius R) as expressed in equation (1):

$$
T_{w}-T_{d}=T=\frac{\pi D^{2} \rho}{4} H R
$$

where $\quad D=$ diameter of the pipe

$\rho=$ density of the fluid

$\frac{\pi D^{2} \rho H}{4}=$ weight of fluid head $(H)$ with flow cross section of $\frac{\pi D^{2}}{4}$

Solving equation (1) for $H$ :

$$
H=\frac{4 T}{\pi D^{2} \rho R}
$$




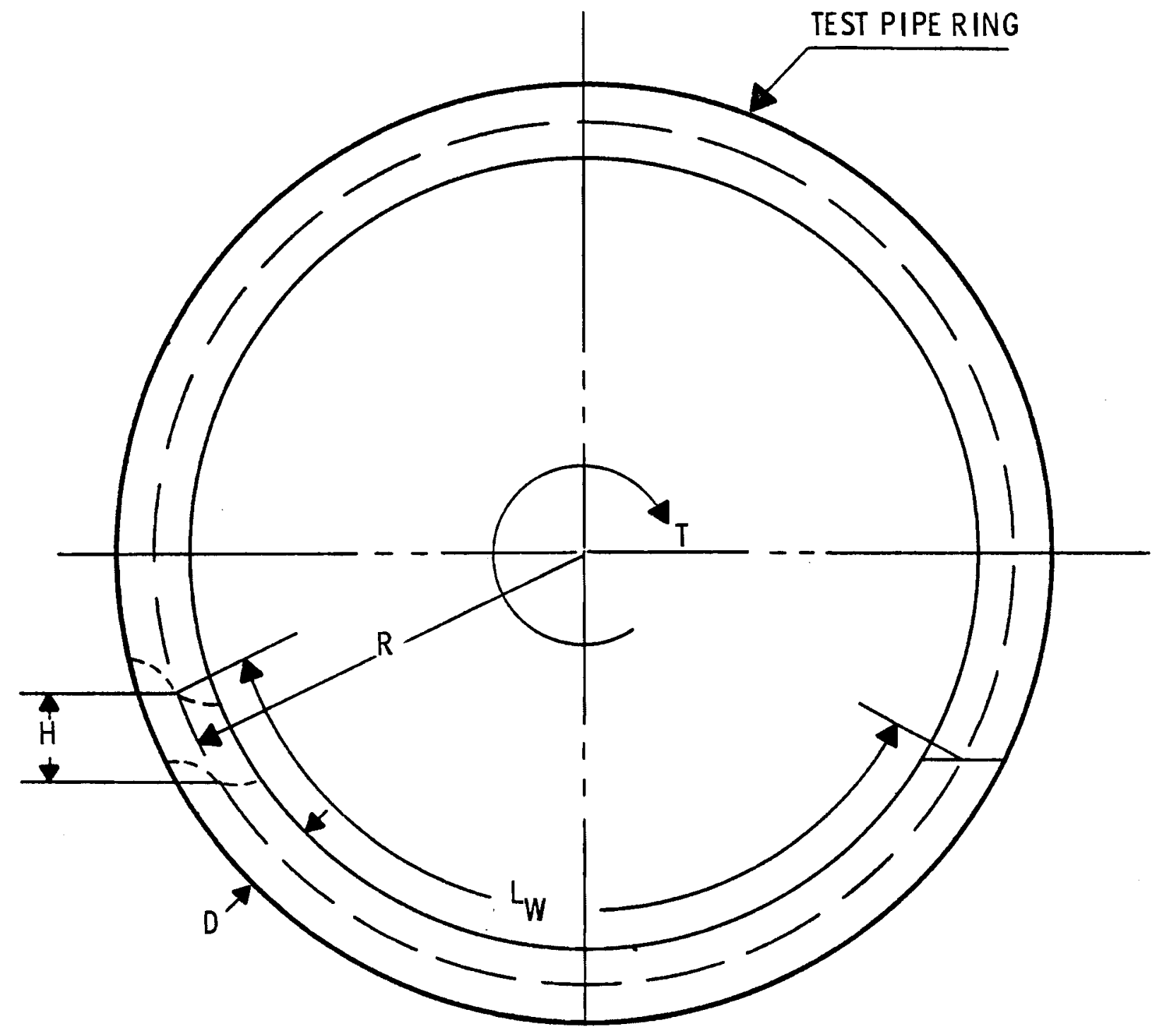

FIGURE 1. Illustration of Head Developed in Test Pipe Ring

To obtain head loss per foot of pipe ( $i)$, the head of fluid $(H)$ is divided by the wetted pipe length, $L_{W}$, where $L_{W}=2 \pi R$ times the fill level in the pipe ring $(1 / 3$ full, etc.):

$$
i=\frac{H}{L_{w}}
$$

A simplification of equation (3) as related to the SETS apparatus is shown in equation (4): 


$$
i=\frac{T}{W R}
$$

where $W=$ weight of fluid put into the pipe ring

$R=$ radius of the pipe ring

If the pipe ring is filled with water only, $i_{w}$ is expressed as feet of water head per foot of pipe. If the pipe ring is filled with a solid-liquid fluid, $i_{f}$ is expressed as feet of fluid head per foot of pipe. To convert feet of fluid head to an equivalent feet of water head, $i_{f}$ is multiplied by a ratio of the densities of water and of fluid as shown in equation (5):

$$
i_{w}\left(\frac{f t \text { of water }}{f t \text { of pipe }}\right)=i_{f}\left(\frac{f t \text { of fluid }}{f t \text { of pipe }}\right) \frac{\rho_{f l u i d}}{\rho_{\text {water }}}
$$

\section{TEST STAND DESCRIPTION}

The following is a brief description of the SETS apparatus. A more detailed description of the SETS apparatus as it was designed and procured is given in C. H. Allen's report (1980). Figure 2 shows the test stand with the components identified. The test stand consists of the following basic components:

- pipe ring and support frame

- drive assembly and controls

- torque and RPM sensors and their respective readouts

- support structure.

The following are brief descriptions of the test stand components.

\section{PIPE RING AND SUPPORT FRAME}

A SETS pipe ring consists of four $90^{\circ}$ bend segments of pipe connected together with bolt-on couplings to form a pipe ring. A typical bolt-on coupling is shown in Figure 3. Two segments of pipe with the associated coupling are shown in Figure 4. The pipe ring is bolted to the support frame and the 


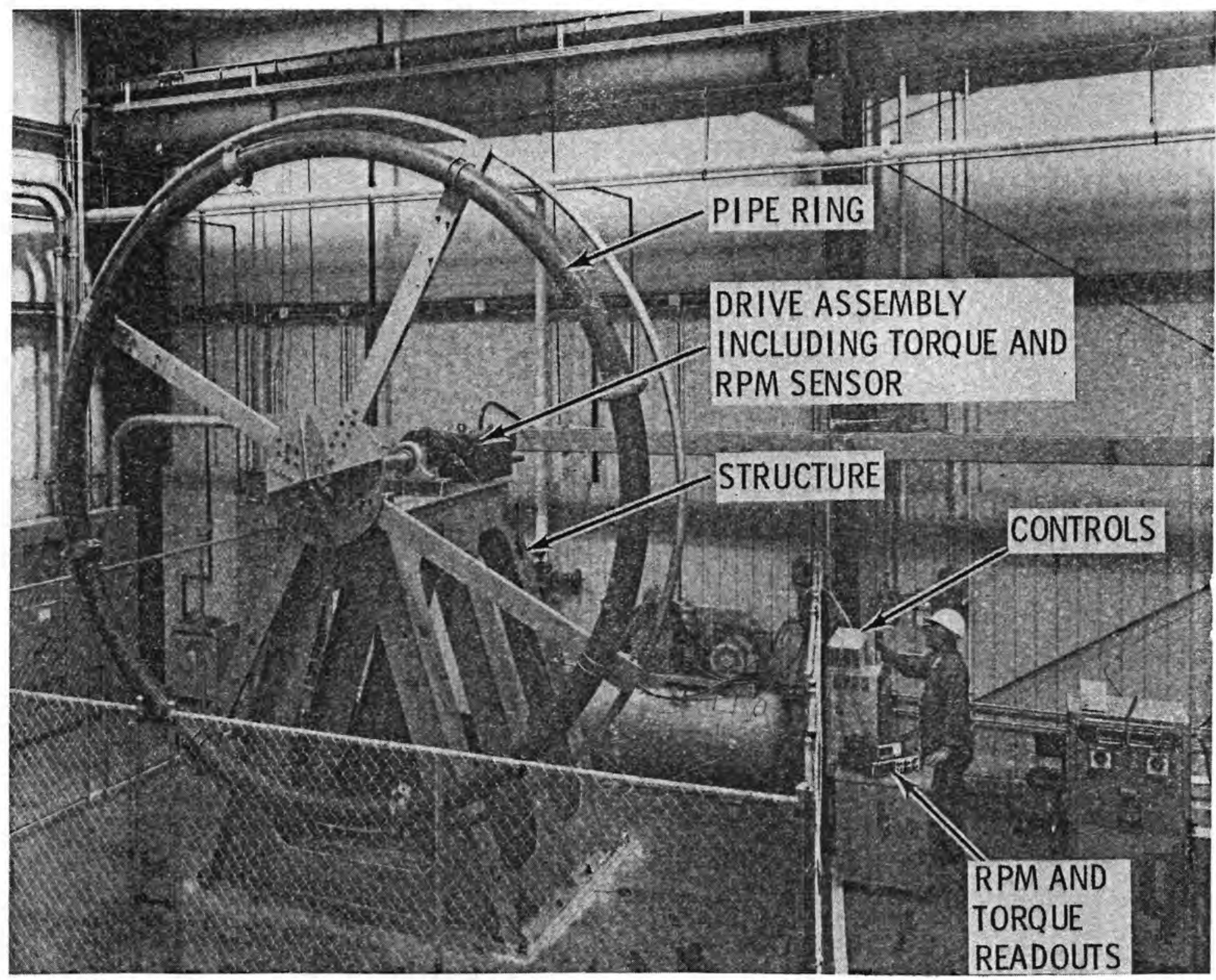

FIGURE 2. Separate Effects Test Stand 


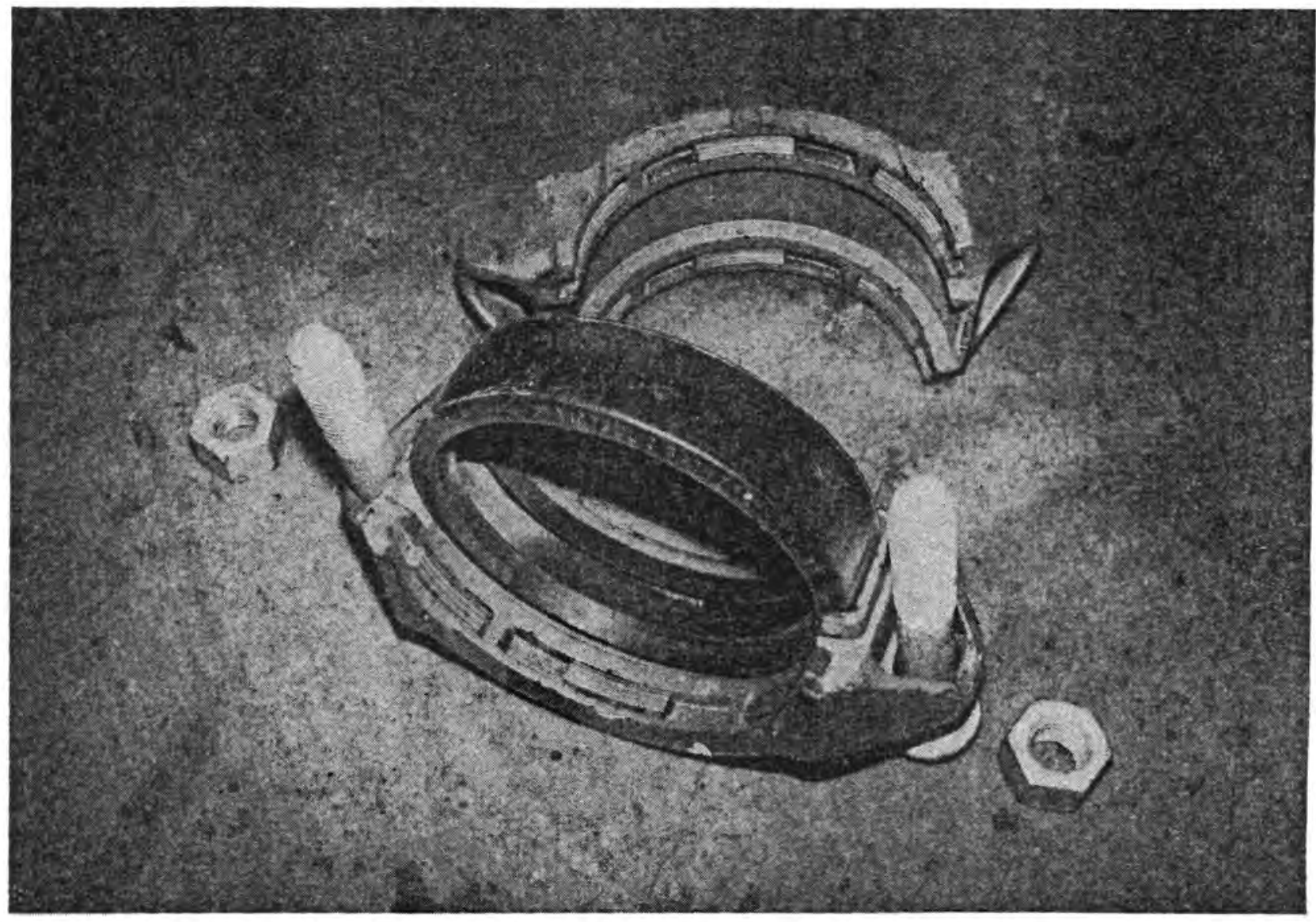

FIGURE 3. Typical Bolt-0n Coupling 


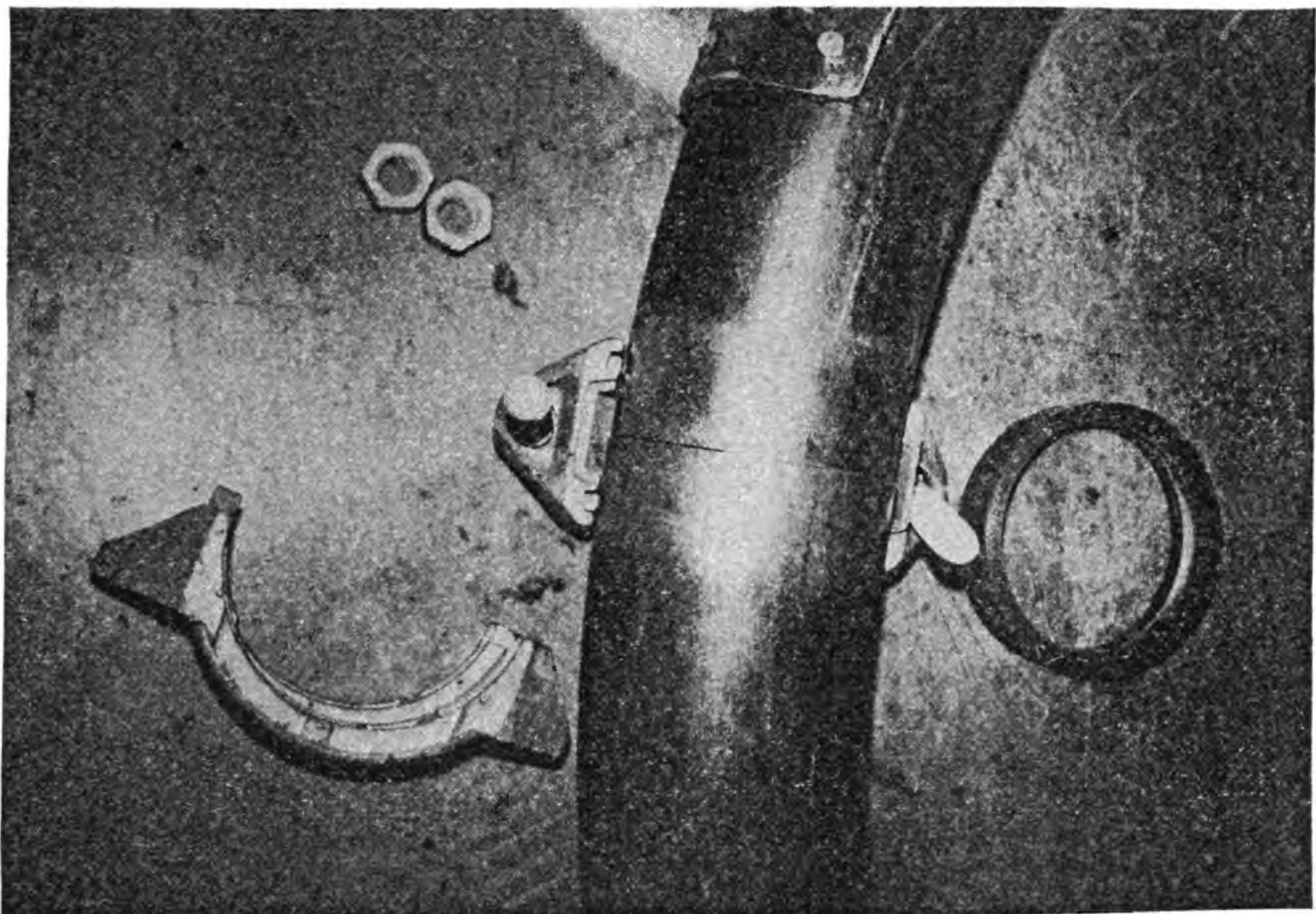

FIGURE 4. Pipe Joint and Coupling 
support frame is bolted to the end of the drive shaft. The support frame, as designed, can hold pipe rings with a maximum outside ring diameter of $14 \mathrm{ft}$ and a maximum pipe diameter of $18 \mathrm{in}$. The following are the sizes of pipe rings that have been fabricated to date using schedule 40 pipe:

\begin{tabular}{|c|c|}
\hline $\begin{array}{l}\text { Nominal Diameter } \\
\text { of Pipe } \\
\end{array}$ & Diameter of Ring \\
\hline 4 in. & $6.27 \mathrm{ft}$ \\
\hline 4 in. & $9.26 \mathrm{ft}$ \\
\hline 4 in. & $12.78 \mathrm{ft}$ \\
\hline 6 in. & $6.41 \mathrm{ft}$ \\
\hline 6 in. & $9.45 \mathrm{ft}$ \\
\hline 6 in. & $13.45 \mathrm{ft}$ \\
\hline $8 \mathrm{in.}$ & $12.42 \mathrm{ft}$ \\
\hline $12 \mathrm{in.}$ & $12.61 \mathrm{ft}$ \\
\hline
\end{tabular}

One modification made to the fabricated pipe rings was to cut a rectangular opening in the outside surface of one pipe segment for a loading and unloading port. Figure 5 shows the loading/unloading port and the cover plate for sealing the port. The portion of the cover plate that actually fits into the opening is constructed to eliminate, as much as possible, any discontinuity of the pipe wall at the cover plate location.

DRIVE ASSEMBLY AND CONTROLS

The drive assembly consists of a 10-hp variable-speed dc motor, a gear reducer, a torque and rpm sensor, and the drive shaft. The drive assembly is capable of rotating a pipe ring and support frame mounted on the end of the drive shaft at from 0 to $68 \mathrm{rpm}$.

TORQUE AND RPM SENSOR AND READOUTS

The torque sensor and its corresponding digital readout are capable of measuring and indicating the torque required to rotate a pipe ring up to 20,000 1b-in. The rpm sensor and its digital readout measure and indicate the rotational speed of the moving ring. The torque sensor signals are fed to a 


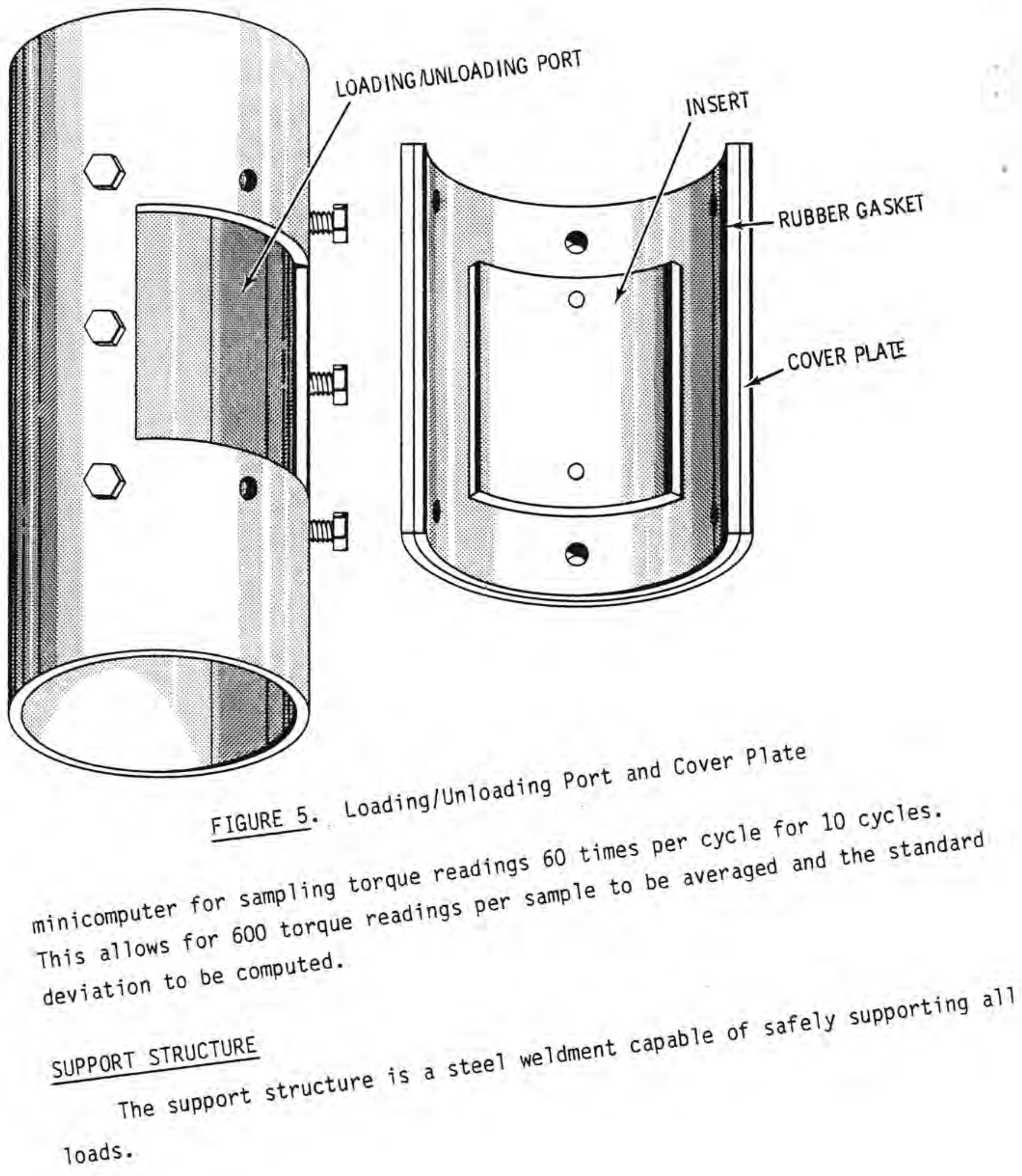




\section{TEST STAND OPERATING PROCEDURE}

The following procedures are those normal operating procedures that do not change or do not change significantly from test to test. Additional or special procedures related to specific tests will be described in the respective section pertaining to the tests.

\section{MOUNTING PIPE RING AND SUPPORT FRAME}

Assuming the SETS apparatus is operable, the first basic operation is to mount a pipe ring on the support frame and then attach the support frame to the drive shaft. The support frame is placed in the horizontal position on the floor, and the pipe ring is maneuvered onto the support frame. The pipe ring is centered on the support frame and bolted with two U-bolts to each support frame spoke. Next the support frame assembly is lifted off the floor in the horizontal position with an overhead crane and placed on a balance stand. The assembly is statically balanced by bolting weights on the support frame spokes until the assembly is horizontally level. Once the assembly has been balanced, it is raised to the vertical position with the crane, moved to the support structure, and bolted to the end of the drive shaft.

\section{LOADING PIPE RING}

Once the support frame and pipe ring are attached to the drive shaft, the pipe ring can be filled with water through one of two 1/2-in. threaded openings or filled with water and/or solids through the loading/unloading port. When the 1/2-in. openings and/or the loading/unloading port are sealed, the pipe ring assembly can be rotated.

\section{ROTATING PIPE RING}

The assembly is rotated by supplying power to the motor from the control panel located outside of the fenced enclosure as seen in Figure 2. The assembly is rotated at the desired speed by manually adjusting the controls until the rpm meter readout displays the desired rpm setting. The torque readings can be read from the digital display of the torque meter readout. The torque 
signals are also sent to a minicomputer in a separate room, for recording the sampled torque values. A revolution counter adds up the number of revolutions the pipe ring makes over a designated period of time. The pipe ring is stopped at the end of a test by shutting off the power to the motor and allowing the assembly to come to rest.

EMPTYING THE PIPE RING

The pipe ring is emptied at the end of a test by positioning the loading/ unloading port at the bottom of the ring above a catch tank. The cover plate is removed from the port and the contents of the pipe ring flow into the catch tank. The contents are then handled as appropriate to the specific test.

\section{PRELIMINARY WATER TESTS}

The preliminary water tests were run to validate the Separate Effects Test Stand as a suitable hydrotransport test apparatus and to choose one pipe ring to run the remainder of the year's tests. The basis of comparison for validation was the Hydraulic Institute Engineering Data Book (1979) values of head or friction loss for flow of water in straight pipe.

\section{WATER TEST PROCEDURES}

Preliminary water tests were run with each of seven pipe rings. Each pipe ring was partially filled with water, rotated at various predetermined speeds, and two samples of torque values were recorded at each of the predetermined speeds. Each pipe ring was also rotated dry and two samples of torque values were recorded at the same speeds as for the partially filled rings. Each pipe ring was filled and rotated at three different fill levels (1/4, 1/3, and 1/2). For each fill level the pipe ring was rotated through a series of predetermined speeds - twice. In other words, torque readings were taken from low speeds to high speeds; the whee 1 was stopped; and then readings were taken from low speeds to high speeds again. The torque readings were converted to head loss data as discussed in the theory section. 
HEAD LOSS RESULTS

Each pipe ring was filled to three different levels to determine any effects of level on the head loss data. The series of predetermined speeds was run to provide data to indicate the relationship between head loss and velocity. Duplicate data were taken to average out any spurious torque readings. The results of these seven water tests are still being analyzed. The final results will be reported in a supplemental report. Considering the variations of the initial SETS data from straight pipe flow data, the 6-in.-diameter pipel 13.45-ft-diameter pipe ring (6-in./13.45-ft ring) was chosen as the best pipe ring to use for further testing. This selection was based on the observation that the head loss data for this pipe ring most closely correlated to the straight pipe flow data.

\section{PRELIMINARY LOCAL COAL TESTS}

The preliminary local coal tests were run to obtain some initial head loss data with various coal-water mixtures. The local coal used for these tests was obtained from a steam plant coal pile located on the Hanford reservation. The coal originally came from Utah.

\section{LOCAL COAL TEST PROCEDURES}

The following is a description of the procedure for running a local coal test. The coal was initially sized in a circular, vibrating screen separator between a 0.875-in. and a 1.50-in. screen for a coal particle average size of 1.2 in. A density measurement of a sample of the average size coal was made for use in determining the volume concentrations of coal and water. Using the density of coal and the density of water, the weights of coal and water were determined for a given volume concentration of coal in water. The calculated amounts of water and coal were weighed separately. The water was drained into the pipe ring, and the coal was manually poured into the pipe ring. The pipe ring was then rotated through a duplicate series of speeds with torque measurements being recorded at each speed. Each of the duplicate series was run from low speeds to high speeds. The contents of the pipe ring were emptied into the 
catch tank at the end of a test and the coal was washed over a 5-mesh screen. The wash water and particles smaller than 5 mesh were washed to a drain. The remaining coal was air dried and then sized in the circular, vibrating screen separator.

\section{HEAD LOSS RESULTS}

The parameters varied in the local coal tests were concentration of coal in water and fill level. Seven tests used the 6-in.-diameter pipe/13.45-ftdiameter pipe ring (6-in./13.45-ft ring). The test matrix for these tests is shown in Table 1. Tests were numbered sequentially. Test numbers that are not called out in this text were extra tests run for confirmation purposes (e.g., Test 4 was a water test rerun). The last three local coal tests used the 6-in./6.41-ft ring. The test matrix for these tests is shown in Table 2. Testing with the 6-in./13.45-ft ring was started with the pipe ring $1 / 2$ full. A distinctive noise during the 1/2-full tests was initially hypothesized to be caused by coal being carried over the top of the pipe ring as it rotated. Based on this hypothesis, it was thought that the supposed coal carryover could be stopped by decreasing the concentration of coal in water in the pipe ring.

TABLE 1. Local Coal Tests Run with 6-in./13.45-ft Ring

\begin{tabular}{|c|c|c|c|}
\hline \multirow{2}{*}{$\begin{array}{l}\text { Concentration of } \\
\text { Local Coal in Water }\end{array}$} & \multicolumn{3}{|c|}{ Fill Level } \\
\hline & $1 / 2$ FuIT & $1 / 3 \mathrm{Fu} I 1$ & $1 / 4$ FuII \\
\hline 15 vol\% & Test 1 & Test 5 & Test 7 \\
\hline 30 vol\% & Test 2 & Test 6 & \\
\hline 45 vol\% & Test 3 & - & \\
\hline
\end{tabular}

TABLE 2. Local Coal Tests Run with 6-in./6.41-ft Ring

\begin{tabular}{|c|c|}
\hline $\begin{array}{l}\text { Concentration of } \\
\text { Local Coal in Water }\end{array}$ & $\begin{array}{l}\text { Fill Leve } 1 \\
1 / 3 \text { Fu11 } \\
\end{array}$ \\
\hline 15 vo $1 \%$ & Test 21 \\
\hline 30 vo $1 \%$ & Test 20 \\
\hline 45 vol\% & Test 19 \\
\hline
\end{tabular}


Thus the 1/3-full tests were run with only the 15 and 30 vol\% concentrations of coal in water and only one 1/4-full test was run at 15 vol\% concentration. This approach lessened the noise but did not eliminate it. It was then decided that future tests would be run at $1 / 3$ full rather than $1 / 2$ full to lessen the supposed coal carryover. Later it was proposed that the noise was caused by the joints of the pipe ring contacting the coal bed in the pipe ring, which was suggested by the fact that the noise consisted of four distinct pulses per revolution of the pipe ring, corresponding to the four pipe joints of the pipe ring. Thus this impact hypothesis is now the best explanation of the rhythmical noise heard during coal tests.

The head loss data obtained for the local coal tests are still being analyzed. The final results will be reported in a supplemental report.

\section{SIZE DEGRADATION RESULTS}

Size degradation data were also obtained from the local coal tests. The size degradation data are plotted in Figures 6 through 9 . Figures 6 through 8 represent tests with 6 -in./13.45-ft ring. Figure 6 represents the 15, 30, and 45 vol\% local coal concentration in water at the 1/2-full level of the pipe ring. These three tests (Tests 1, 2, and 3) were run between 67 and 75 minutes per test. Figure 7 represents the 15 and 30 vol\% local coal concentration in water at the 1/3-full level of the pipe ring. These two tests (Tests 5 and 6 ) were run between 61 and 63 minutes per test. Figure 8 represents the 15 vol\% local coal concentration in water at the 1/4-full level of the pipe ring. This test (Test 7) was run for 60 minutes. Figure 9 represents tests with the 6 -in.16.41-ft ring. Figure 9 represents the 15, 30, and 45 vol\% local coal concentration in water at the 1/3-full level of the pipe ring. These three tests (Test 21, 20, and 19) were all run for 35 minutes per test. A11 the tests mentioned previously were run with coal particles with 1.2-in. initial average size local coal. Size degradation is related to coal-coal collisions, coal-pipe contact, and coal-pipe joint contact. The pipe joints in the SETS pipe rings correspond to pipe joints in an underground hydrotransport piping system. The distance between pipe joints in the 6-in./13.45-ft pipe ring 


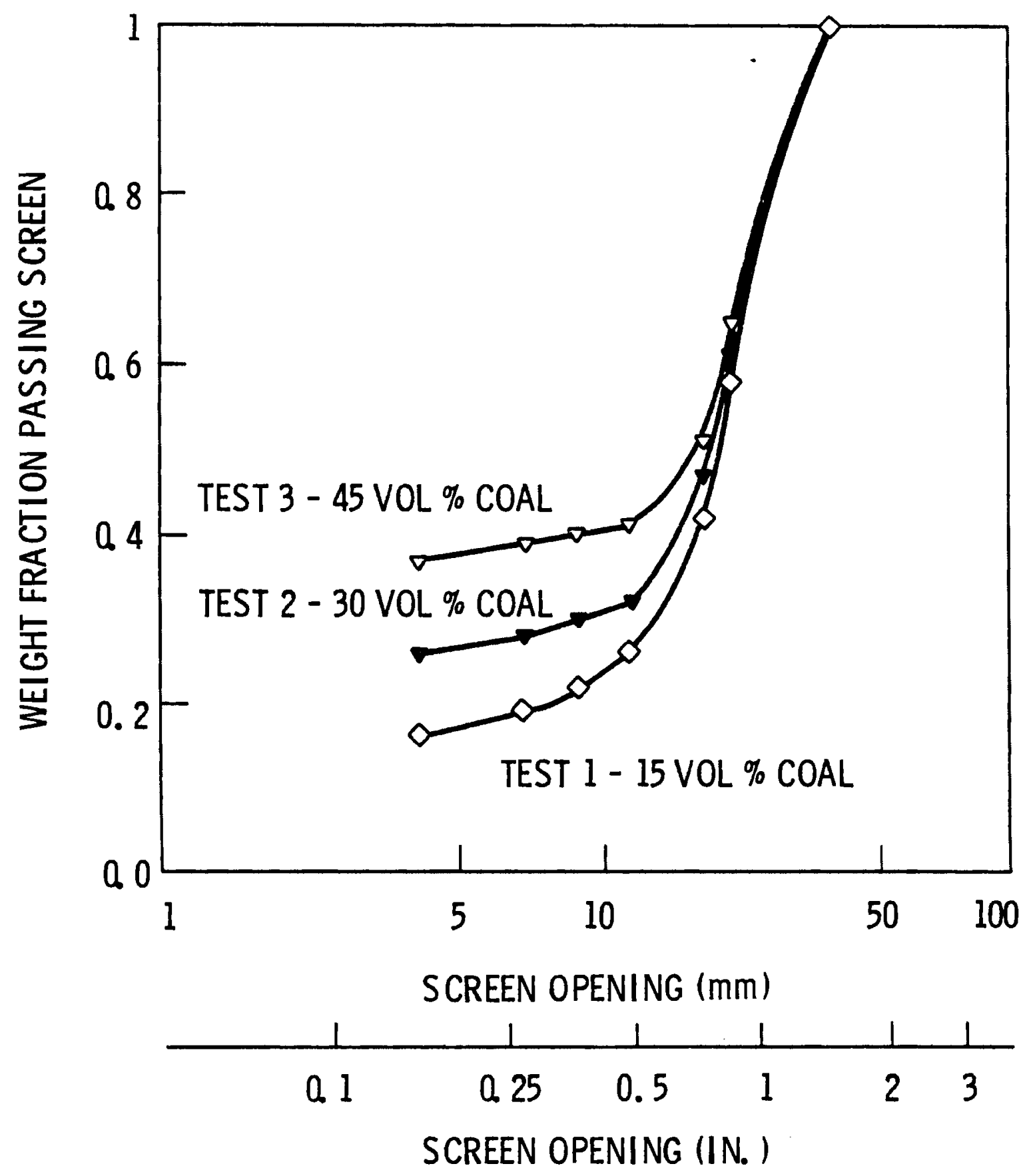

FIGURE 6. Local Coal Size Degradation for Tests 1,2 , and 3 

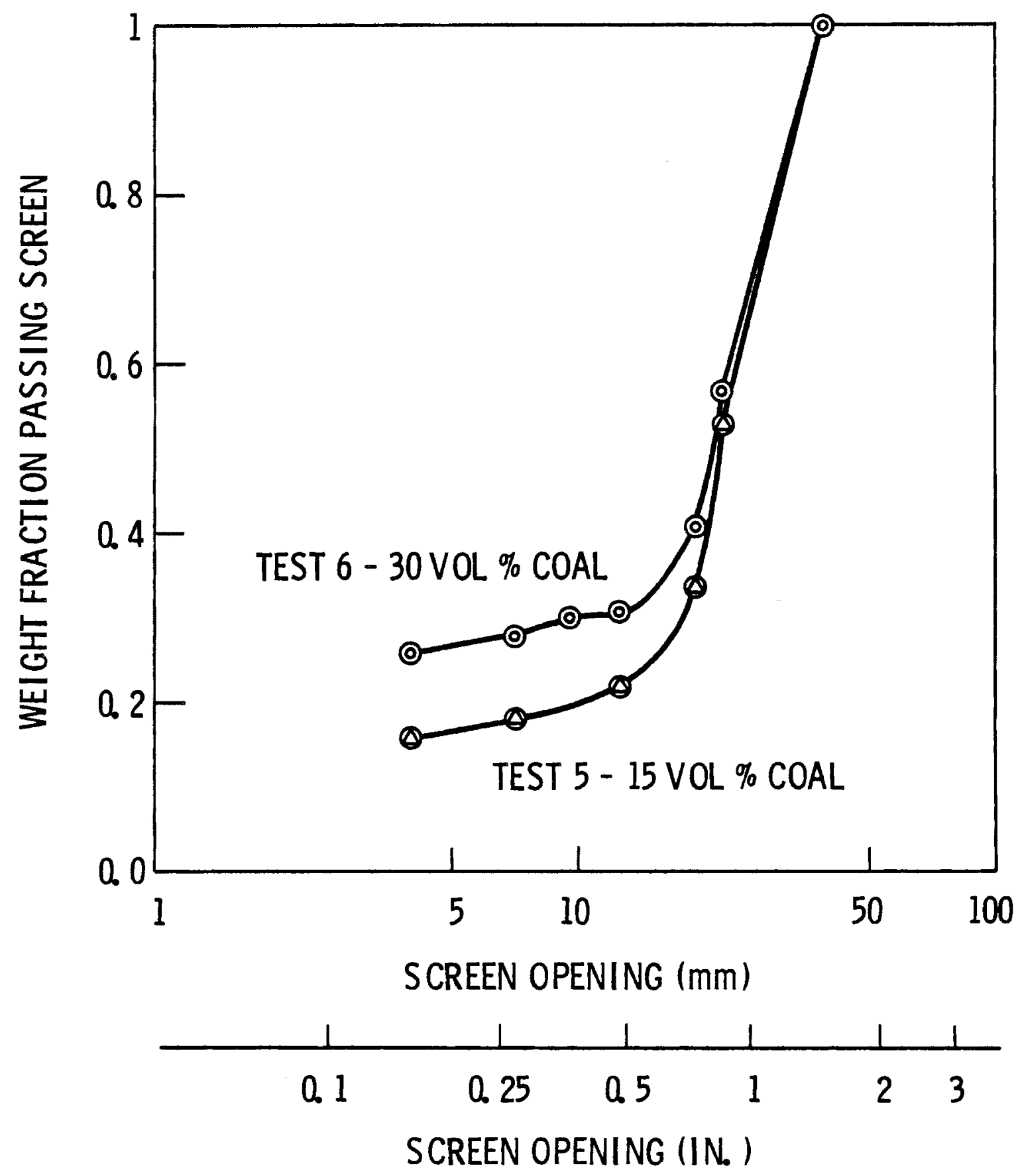

FIGURE 7. Local Coal Size Degradation for Tests 5 and 6 


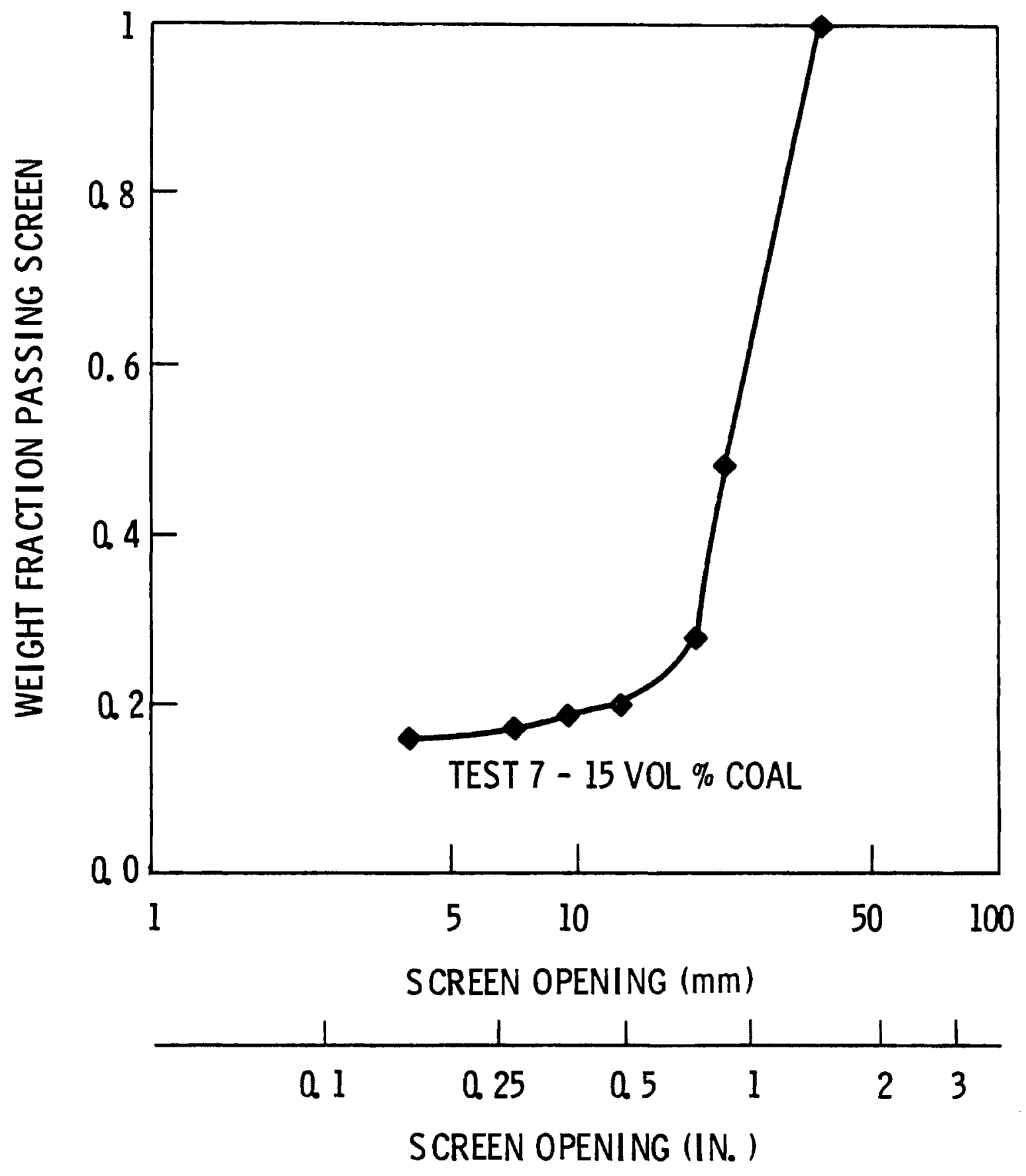

FIGURE 8. Local Coal Size Degradation for Test 7 


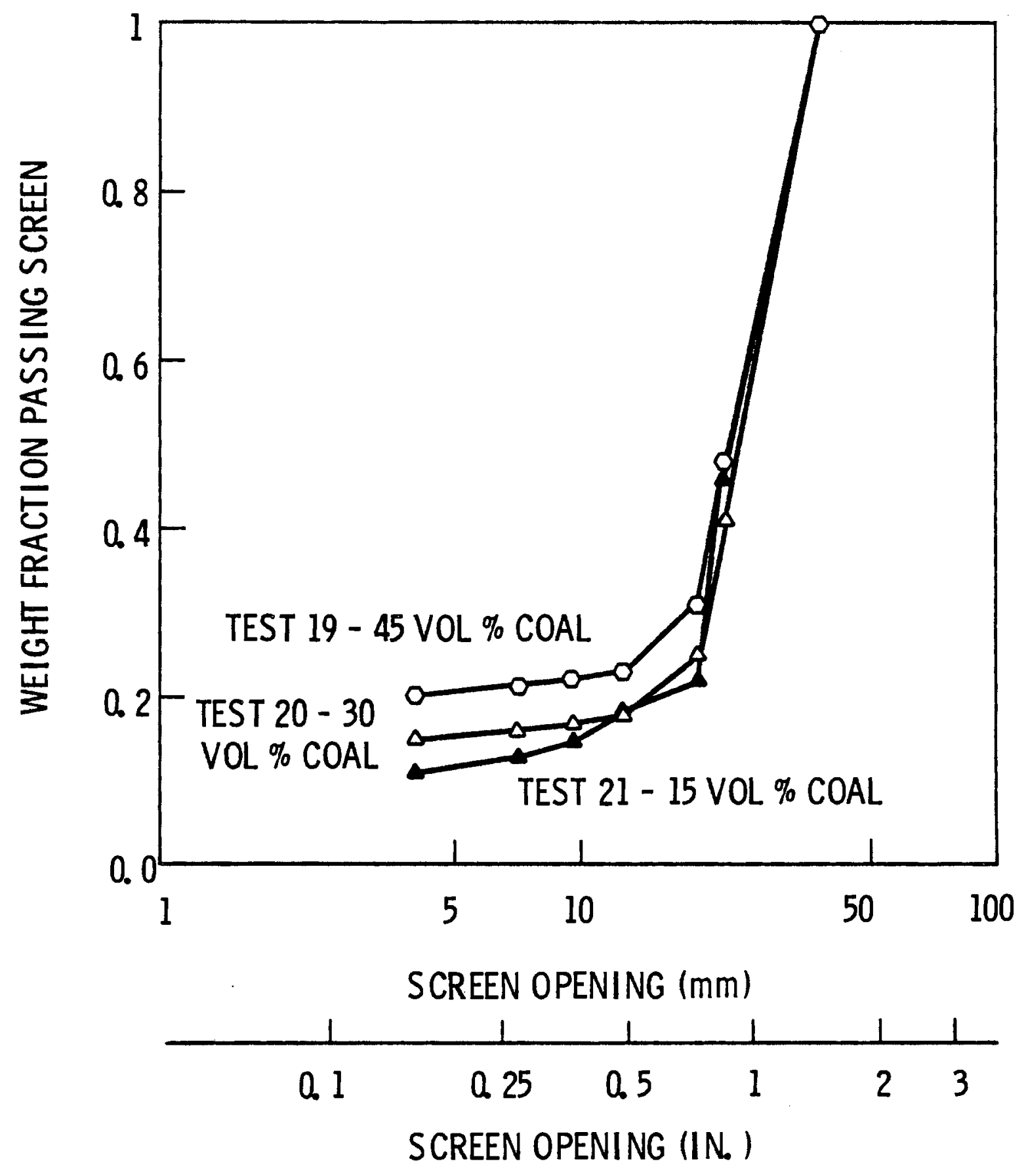

FIGURE 9. Local Coal Size Degradation for Tests 19, 20, 21 
is about $10 \mathrm{ft}$ which is considered in the realistic range for an underground hydrotransport piping system. The data indicates that coal particles smaller than 5 mesh increase linearly with increasing concentration of coal in water between 35 and 75 minutes of testing time. This correlation is apparently not affected by the fill level and is consistent between the two different ring sizes tested.

\section{WATER QUALITY TESTS}

The water quality tests were run to determine the effects of coarse coal hydrotransport on water quality as it relates to wastewater treatment and disposal. Since Pittsburgh Seam coal and the associated refuse are used in the DOE's Hydraulic Transport Research Facility (HTRF), Pittsburgh Seam coal and refuse were used for the SETS water quality tests. The Pittsburgh Seam coal and associated refuse used in the SETS tests were obtained from Federal No. 2 mine in West Virginia.

\section{WATER QUALITY TEST PROCEDURES}

The following is a description of the normal procedure for running a water quality test. The coal and the refuse were initially independently sized in a circular, vibrating screen separator to average sizes of either $1.2 \mathrm{in.,}$ $0.6 \mathrm{in.}$, or $0.3 \mathrm{in.}$ The following gives the two screen sizes used to yield the previously given average size particles:

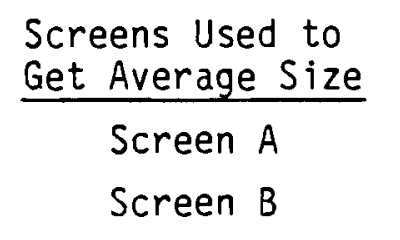

\begin{tabular}{|c|c|c|}
\hline \multicolumn{3}{|c|}{ Average Size } \\
\hline $1.2 \mathrm{in.}$ & 0.6 in. & $0.3 \mathrm{in.}$ \\
\hline 1.50 & 0.75 in. & $0.375 \mathrm{in.}$ \\
\hline .875 & $\begin{array}{l}0.437 \text { in. } \\
(2 \text { mesh })\end{array}$ & $\begin{array}{l}0.279 \text { in } \\
\text { (3 mesh) }\end{array}$ \\
\hline
\end{tabular}

Density measurements of samples of average sized coal and refuse particles were made for use in determining the volume concentrations of coal, refuse, and water. Using the densities of coal and refuse and the density of water, the weights of coal, refuse and water were determined for a given volume 
concentration of solids (coal or coal and refuse) in water. The calculated amounts of water, coal and refuse were weighed separately. The water was drained into the pipe ring, and the solids were manually poured into the pipe ring. The pipe ring was then rotated at a predetermined speed for a specified number of cycles.

Periodically during the test, the pipe ring was stopped to take a water quality sample. The sample was drawn from a sampling port at a location just below the liquid level in the pipe ring. These periodic water quality samples were tested for $\mathrm{pH}$ and Dissolved Oxygen (DO) concentration. After the sample was drawn, the pipe ring was again rotated at the same predetermined speed until another sample was to be drawn or the test was terminated. The total number of cycles run in a test was planned to correspond to test time periods of 1,5 , or 10 hours. At the end of a test, the contents of the pipe ring were emptied into the catch tank. As the initial fluid was emptied into the catch tank, it was filtered through a 5 mesh screen into a 5 gallon bucket. A water quality sample was taken from the unfiltered fluid in the catch tank and a second sample was taken from the filtered fluid in the 5-gallon bucket after it has settled for 10 minutes. These two samples were sent to the chemistry labs for detailed analysis. The coal or coal and refuse in the catch tank was washed over a 5 mesh screen. The wash water and particles smaller than 5 mesh were washed to a drain. The remaining coal or coal and refuse was air dried and then sized in the circular vibrating screen separator.

\section{WATER QUALITY RESULTS}

The parameters varied in the water quality tests were test time and initial average size of particles. All the water quality tests were run with the 6-in.-diameter pipe/13.45-ft-diameter pipe ring (6-in./13.45-ft ring). A11 but one test (Test 10) were run at 45 vol\% concentration of solids (coal or coal and refuse) in water. Test 10 was run at 15 vol\% concentration of solids in water and provided a comparison of the effect of concentration on the water quality. The test matrix is shown in Table 3. Initial tests used 10-hour time periods; the 5-hour and 1-hour time periods were subsequently chosen based on the 10-hour test results. Baseline tests with coal only were run for coal 
TABLE 3. Water Quality Tests (a)

\begin{tabular}{|c|c|c|c|}
\hline \multirow{2}{*}{$\begin{array}{l}\text { Average Size of } \\
\text { Coal and Refuse }\end{array}$} & \multicolumn{3}{|c|}{ Test Time Period } \\
\hline & $10 \mathrm{hr}$ & $5 \mathrm{hr}$ & $1 \mathrm{hr}$ \\
\hline $1.2 \mathrm{in.}$ & $\begin{array}{l}\text { Test } 10 \text { (Coal only) } \\
\text { Test } 11 \text { (Coal only) } \\
\text { Test } 12\end{array}$ & Test 13 & Test 14 \\
\hline $0.6 \mathrm{in.}$ & Test 24 & Test 23 & $\begin{array}{l}\text { Test } 22 \text { (Coal only) } \\
\text { Test } 25\end{array}$ \\
\hline $0.3 \mathrm{in.}$ & $\begin{array}{l}\text { Test } 26 \text { (foal only) } \\
\text { Test } 27 \text { (b) }\end{array}$ & - & Test 28 \\
\hline
\end{tabular}

(a) All tests are run with coal and refuse unless otherwise designated.

(b) Test 27 actually ran about $6 \mathrm{hr}$ and then it was terminated.

particles of each average size for comparison to the coal and refuse results. The majority of the tests were run at 45 vol\% concentration as a worst-case indication of the effect on water quality for tests of coal and refuse. The coal occupied 36 vol\% and the refuse 9 vol\%.

One of the most important results of the water quality tests was the discovery of the production of a thick foam during certain tests containing coal and refuse. No foams were apparent in tests with coal only. The tests that generated foam were Tests $14,24,25,27$, and 28 . The smaller the average size of the initial particles, the higher the probability of the foam production. With 0.3-in. initial average size coal and refuse particles, foam was produced with the "10"-hour and the 1-hour tests so no 5-hour test was deemed necessary. The "10" hour test actually only ran about 6 hours: the foam became so thick it rotated centrifugally with the pipe ring because of the increased friction force, so the test was terminated. In some tests the foam was so thick that no liquid samples were obtainable for analysis. Tests 27 and 28 yielded no detailed chemistry analysis for this reason.

The foam discovered during the water quality tests varied in thickness. At its thickest, it was like a thick, black whipped cream that was capable of supporting an item such as a screwdriver in the vertical position. The consistency of the foam can be seen in Figures 10,11,12, and 13. Based on a 


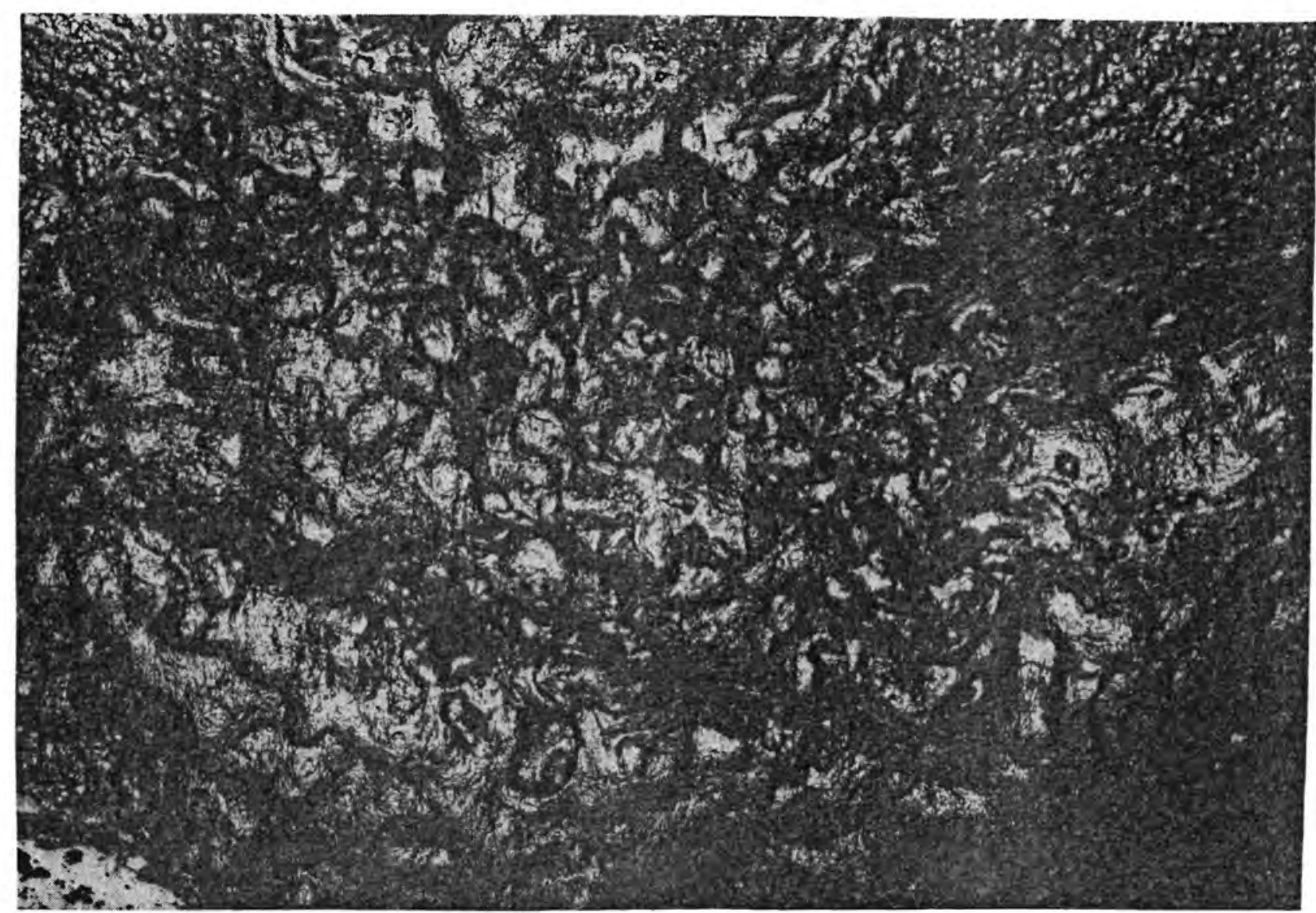

FIGURE 10. Foam Generated During Test 14 


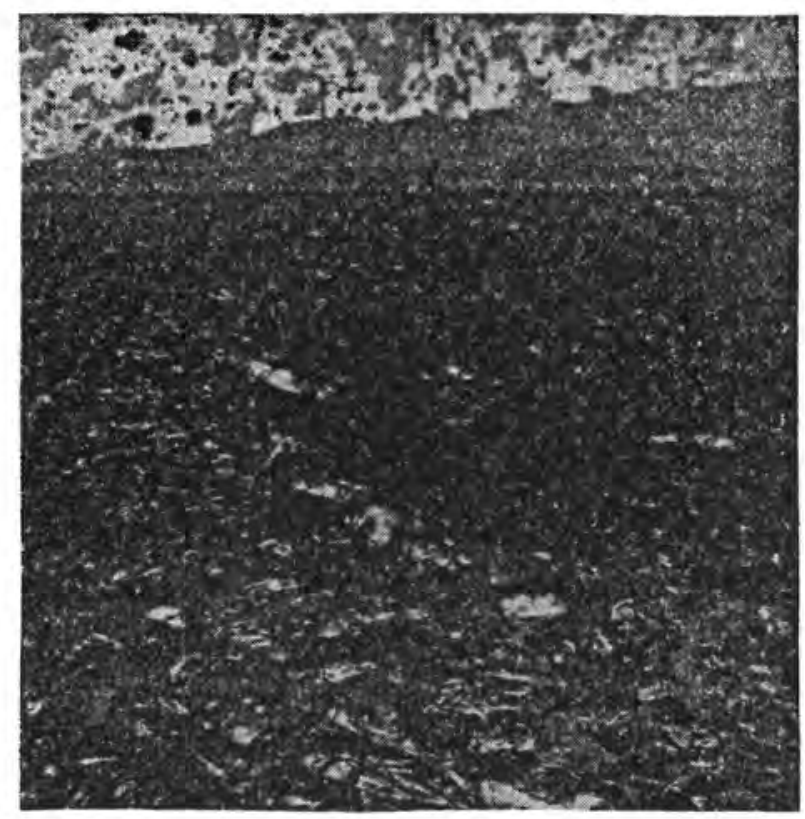

FIGURE 11. Foam Generated During Test 24

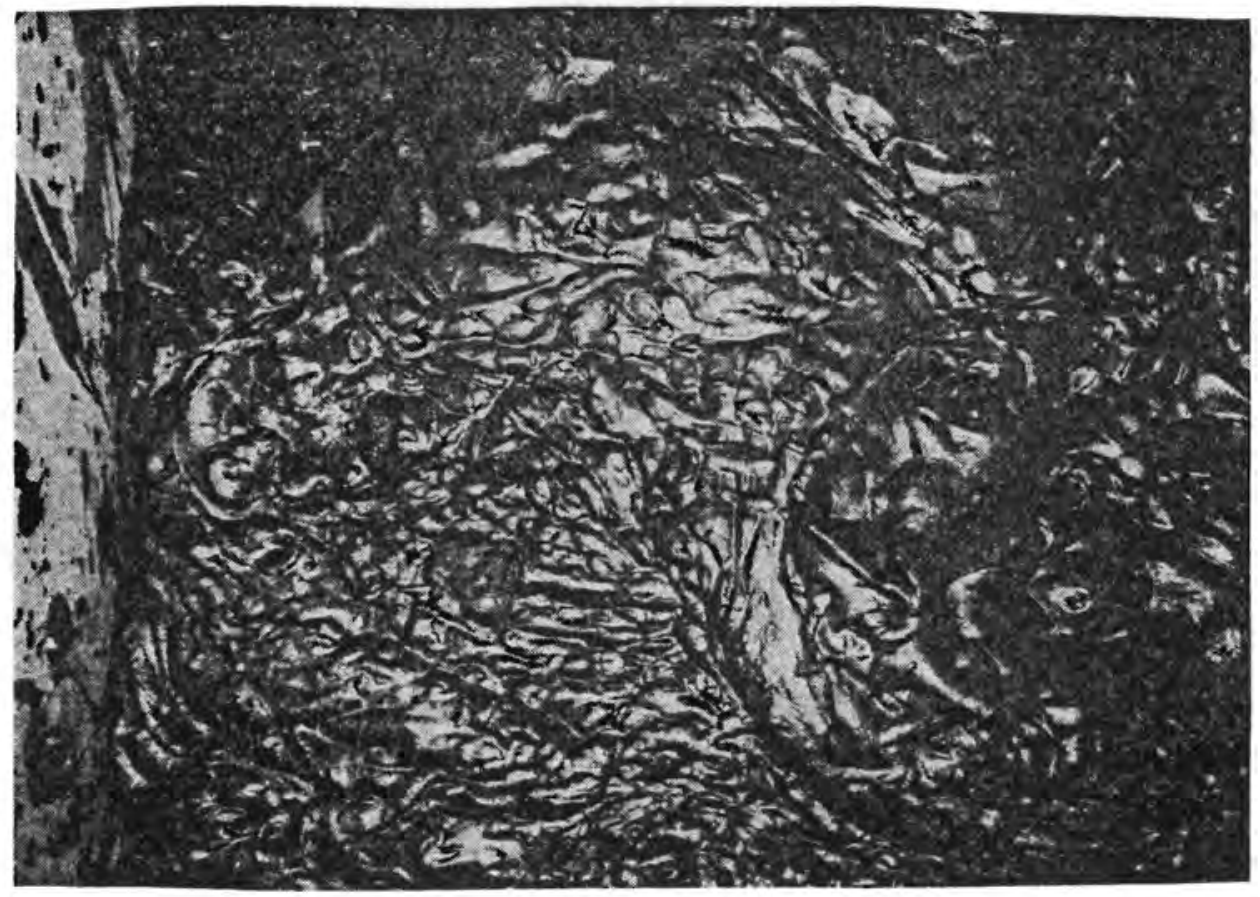

FIGURE 12. Foam Generated During Test 27 


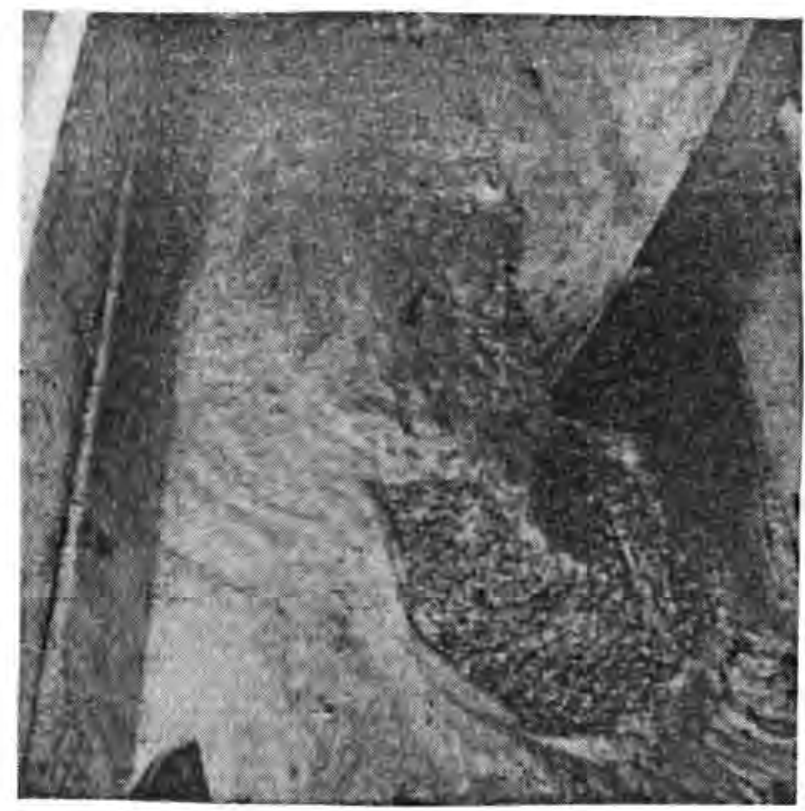

FIGURE 13 . Foam Generated During Test 28

previous report (Schriek et a1. 1973), the Canadians reported generating a foam or "gell" by whipping coal and water in a blender. The hypothesis put forth by these researchers was that small bubbles of air become trapped by large amounts of coal fines. The SETS foam was probably generated not only by the air bubbles and fine particles but also by the frothing properties of the refuse constituents. Further research is necessary to characterize the foam and discover how to either inhibit its generation or break up the foam after it is formed. If set aside to dry, the foam forms a low-density solid of almost the same volume as the wet foam. The solid foam does have some compressive strength. The air bubbles do not appear to collapse during the drying period.

Most of the water quality analysis was based on the following parameters:

- $\mathrm{pH}$

- conductivity

- alkalinity

- suspended solids (also known as nonfilterable residue)

- calcium 
- magnesium

- sulfate

- Chemical Oxygen Demand (COD)

- Dissolved Organic Carbon (DOC)

- chloride

- fluoride

These parameters are defined and their significance described in Appendix A.

No conclusions were made from the pH and Dissolved Oxygen (DO) measurements made on water quality samples taken during the course of an individual test. The DO measurements were erratic; part of the reason for this was related to the foam generation. In tests where foam was generated, water quality samples were not always obtainable with sufficient liquid to allow a good 00 measurement. Also the DO probe membrane often became coated with fine particles which could have affected the measurements. The pH changed a maximum of only 0.4 and the average change was closer to 0.2 . This amount of change in $\mathrm{pH}$ was not considered significant.

Based on the previously listed parameters, detailed analytical data was obtained for ten out of the twelve water quality tests that were run. The results of the detailed analysis on samples taken at the end of an individual test are shown in Table 4. Two samples were collected for each test except Test 24. Samples designated by "A" in Table 4 were taken directly from the pipe ring just below the liquid level at the end of the test. Samples designated by "B" in Table 4 were taken from the supernatant liquid after the contents of the pipe ring were sieved through a 5-mesh screen into a bucket and allowed to settle for 10 minutes. Due to foam generation during Test 24, no "A" sample of liquid was obtainable. Foam was generated during Tests 27 and 28 and no liquid samples, "A" or "B", were obtainable for analysis. All analyses, except conductivity and suspended solids, were performed on a filtrate collected by filtering a well mixed portion of each sample on a 0.45 micron membrane filter.

The following sections describe some general trends that can be seen from the detailed analytical data. For clarity and comparison, selected data from Table 4 are reproduced in subsequent tables to illustrate specific results. 
TABLE 4. Analytical Water Quality Data

\begin{tabular}{|c|c|c|c|c|c|c|c|c|c|c|c|}
\hline & $\mathrm{pH}$ & $\begin{array}{c}\text { Conductivity } \\
\text { umhos } / \mathrm{cm} \\
\end{array}$ & $\begin{array}{c}\text { Alkalinity } \\
(\mathrm{mg} / 1) \\
\text { as } \mathrm{CaCO}_{3} \\
\end{array}$ & $\begin{array}{l}\text { Suspended } \\
\text { Solids } \\
(\mathrm{g} / 1) \\
\end{array}$ & $\begin{array}{c}\mathrm{Ca} \\
(\mathrm{mg} / \mathrm{l}) \\
\end{array}$ & $\begin{array}{c}\mathrm{Mg} \\
(\mathrm{mg} / 1) \\
\end{array}$ & $\begin{array}{l}\text { Sulfate } \\
(m g / 1)\end{array}$ & $\begin{array}{c}C 00 \\
(m g / 1) \\
\end{array}$ & $\begin{array}{c}00 C \\
(m g / 1)\end{array}$ & $\begin{array}{l}\mathrm{Cl}^{-} \\
(\mathrm{mg} / \mathrm{l}) \\
\end{array}$ & $\begin{array}{c}F^{-} \\
(m g / 1)\end{array}$ \\
\hline $\begin{array}{l}\text { Raw Water } \\
\text { Blank }\end{array}$ & $r$ & 240 & 94.4 & 0.105 & 30.8 & 6.52 & 15.8 & $<10$ & $<3$ & - & - \\
\hline $\begin{array}{r}\text { Test } 10 \mathrm{~A} \\
\mathrm{~B}\end{array}$ & $\begin{array}{ll}\text { A } & 7.10 \\
\text { B } & 7.40\end{array}$ & $\begin{array}{l}480 \\
520\end{array}$ & $21 \overline{2}$ & $\begin{array}{l}9.50 \\
6.50\end{array}$ & $\begin{array}{l}70.4 \\
65.5\end{array}$ & $\begin{array}{l}7.61 \\
7.49\end{array}$ & $\begin{array}{l}55 \\
32\end{array}$ & $\begin{array}{l}- \\
-\end{array}$ & $\begin{array}{l}5.2 \\
7.8\end{array}$ & - & - \\
\hline Test 11 A & $\begin{array}{ll}A & \overline{7} \\
B & 7.50\end{array}$ & $\begin{array}{l}440 \\
425\end{array}$ & $23 \overline{8}$ & $48 \overline{8}$ & $\begin{array}{l}73.8 \\
74.4\end{array}$ & $\begin{array}{l}7.90 \\
7.33\end{array}$ & $\overline{76}$ & - & $\overline{12} .2$ & $\begin{array}{l}- \\
-\end{array}$ & $\begin{array}{l}- \\
-\end{array}$ \\
\hline Test 12 A & $\begin{array}{ll}\text { A } & 7.05 \\
\text { B } & 7.05\end{array}$ & $\begin{array}{l}625 \\
660\end{array}$ & $38 \overline{8}$ & $\begin{array}{l}535 \\
544\end{array}$ & $\begin{array}{l}94.7 \\
92.3\end{array}$ & $\begin{array}{l}12.1 \\
11.7\end{array}$ & $\begin{array}{l}276 \\
328\end{array}$ & $2 \overline{5} .7$ & $\begin{array}{r}8.8 \\
13.8\end{array}$ & $\begin{array}{l}- \\
-\end{array}$ & - \\
\hline Test 13 A & $\begin{array}{ll}A & 7.0 \\
B & 7.05\end{array}$ & $\begin{array}{l}750 \\
670\end{array}$ & $\begin{array}{l}344 \\
333\end{array}$ & $\begin{array}{l}472 \\
479\end{array}$ & $\begin{array}{l}90.5 \\
88.7\end{array}$ & $\begin{array}{l}10.8 \\
10.8\end{array}$ & $35 \overline{0}$ & $\begin{array}{l}502 \\
502\end{array}$ & $\begin{array}{l}160 \\
156\end{array}$ & $\overline{43}$ & $\overline{0} .23$ \\
\hline Test 14 A & $\begin{array}{ll}A & 7.0 \\
B & 7.0\end{array}$ & $\begin{array}{l}825 \\
900\end{array}$ & $\begin{array}{l}412 \\
452\end{array}$ & $10 \overline{8}$ & $\begin{array}{l}80.3 \\
79.0\end{array}$ & $\begin{array}{l}7.50 \\
7.50\end{array}$ & $12 \overline{0}$ & $\begin{array}{l}8,410 \\
8,880\end{array}$ & $\begin{array}{l}2,637 \\
2,647\end{array}$ & - & - \\
\hline $\begin{array}{r}\text { Test } 22 \mathrm{~A} \\
\mathrm{~B}\end{array}$ & $\begin{array}{ll}\text { A } & 7.2 \\
\text { B } & 7.3\end{array}$ & $\begin{array}{l}600 \\
650\end{array}$ & $\begin{array}{l}187 \\
184\end{array}$ & $\begin{array}{l}200 \\
146\end{array}$ & $\begin{array}{r}99.4 \\
102.0\end{array}$ & $\begin{array}{l}6.50 \\
6.34\end{array}$ & $23 \overline{0}$ & $\begin{array}{l}239 \\
239\end{array}$ & $\begin{array}{l}88.5 \\
91.0\end{array}$ & $\overline{18}$ & $\overline{0} .2$ \\
\hline $\begin{array}{r}\text { Test } 23 \mathrm{~A} \\
\mathrm{~B}\end{array}$ & $\begin{array}{ll}\text { A } & 7.2 \\
\text { B } & 7.2\end{array}$ & $\begin{array}{l}710 \\
740\end{array}$ & $\begin{array}{l}331 \\
331\end{array}$ & $\begin{array}{l}507 \\
498\end{array}$ & $\begin{array}{l}82.3 \\
91.3\end{array}$ & $\begin{array}{l}11.5 \\
11.7\end{array}$ & $37 \overline{0}$ & $\begin{array}{l}41 \\
39\end{array}$ & $\begin{array}{l}15.8 \\
15.3\end{array}$ & $\overline{44}$ & $\overline{0} .44$ \\
\hline Test $24 B$ & 7.80 & 1,650 & 332 & 3.40 & 48.4 & 11.2 & - & 3,490 & - & - & - \\
\hline $\begin{array}{r}\text { Test } 25 \mathrm{~A} \\
\mathrm{~B}\end{array}$ & $\begin{array}{ll}A & 7.0 \\
B & 7.0\end{array}$ & $\begin{array}{l}1,010 \\
1,080\end{array}$ & $\begin{array}{l}460 \\
480\end{array}$ & $\begin{array}{l}304 \\
301\end{array}$ & $\begin{array}{l}125 \\
118\end{array}$ & $\begin{array}{l}11.5 \\
11.2\end{array}$ & - & $\begin{array}{l}9,422 \\
8,959\end{array}$ & $\begin{array}{l}2,892 \\
2,907\end{array}$ & - & - \\
\hline $\begin{array}{r}\text { Test } 26 \mathrm{~A} \\
\mathrm{~B}\end{array}$ & $\begin{array}{ll}A & 7.3 \\
B & 7.3\end{array}$ & $\begin{array}{l}650 \\
650\end{array}$ & $\begin{array}{l}127 \\
137\end{array}$ & $\begin{array}{l}269 \\
264\end{array}$ & $\begin{array}{l}138 \\
138\end{array}$ & $\begin{array}{l}8.6 \\
8.6\end{array}$ & - & $\begin{array}{l}99 \\
99\end{array}$ & $\begin{array}{l}33 \\
32\end{array}$ & - & - \\
\hline
\end{tabular}


The outstanding characteristic of the liquid samples as received is the very high suspended solids contents. The suspended solids exceeded $100 \mathrm{~g} / 1$ in all tests except Text 10 and Test 24. The lower suspended solids value for Test 10 is related to a lower coal concentration in water in Test 10 versus the other tests. The lower suspended solids value for Test 24 is related to the foam generated in that test. The foam appears to act as a filter for fines thus yielding a small quantity of filtered liquid for a sample. The suspended solids content of the test samples is generally much higher than primary blackwater effluent from a coal preparation plant which typically ranges from 10 to $50 \mathrm{~g} / 1$. Suspended solids in the wastewater discharge from coal preparation plants is currently limited by EPA Effluent Standards to $70 \mathrm{mg} / 1$ for one day and an average of $35 \mathrm{mg} / 1$ for 30 days (EPA, 40 CFR 434). Based on these standards removal of suspended solids is important.

Chemical Oxygen Demand (COD) and Dissolved Organic Carbon (DOC) were very high on samples 14,24 , and 25 . This appears to be related to the foam generation.

The $\mathrm{pH}$ and alkalinity data indicate minimal or no acid formation due to oxidation of reduced sulfur species (e.g., pyrites). 0xidation of pyrites to form sulfuric acid is manifested by low pH levels (3-5), low alkalinities, high iron, and sulfate concentrations. A small reduction in $\mathrm{pH}$ between raw water (blank) and the test samples was observed, but the alkalinities increased in every case. Sulfate levels increased but this may result from dissolution of minerals such as gypsum contained in the coal. EPA standards limit pH to a range of 6 to 9 . Based on these standards, control of pH does not appear to be a problem for wastewater disposal.

The EPA effluent standards are designated for discharge to surface receiving waters such as rivers, streams, and lakes. Discharge into a municipal sewer would not necessarily be controlled by these same standards. For small volume discharges, the major concern is the presence of toxic substances which may upset the operation of the sewage treatment plant and contribute to 
pollution in the plant effluent. Suspended solids and organic substances in relatively small inputs to the sewage treatment are usually not considered to be problems. Control of $\mathrm{pH}$ to a range of 6 to 9 is normally required for discharge to sewer systems.

Sulfate was determined by the barium sulfate turbidometric method (American Public Health Assoc., 1975) on samples 10, 11, and 12. Attempts to use this same method on subsequent samples were unsuccessful due to the presence of interfering substances (probably organic matter). Samples 13-B, 14-B, $22-B$, and 23-B were analyzed for sulfate, chloride, and fluoride by ion chromatography.

Conductivity values for the test samples were 1.8 to 6.9 times higher than the tap water blank which reflects the dissolution of electrolytes from the coal and possibly some oxidation of reduced sulfur species. Calcium increased by factors of 1.6 to 4.5 over the tap water value while magnesium increased from 0 to 1.9 times the tap water value. Dissolved electrolytes do not appear to be excessive and should not be a problem for discharge to a sewer system or to most receiving waters. Potable waters in the United States generally range from 50 to $1500 \mu$ mhos/cm.

Heavy metals determined by inductively coupled plasma arc spectroscopy of sample 14-B are presented in Table 5 along with primary and secondary drinking water standards. Test samples were analyzed by phenanthroline spectrophotometric method for total iron which yielded results below the detection limit $(0.05$ or $0.1 \mathrm{mg} / 1)$ for al1 samples except 12-A, 12-B, and 26-B. These were $0.16,0.22$, and $0.06 \mathrm{mg} / 1$, respectively. Subsequent analys is of sample 14-B by inductively coupled plasma arc spectroscopy (ICP) disclosed an iron value of $0.75 \mathrm{mg} / 1$ which casts some doubt on the accuracy of the results obtained by the phenanthroline method. Organic interferences could be a problem with the phenanthroline method due to complexation of the iron. Iron complexation could prevent the formation of the orange-red color necessary for the spectrophotometric method. Attempts to eliminate the interference in the samples by oxidation of the organic matter with perchlorate, persulfate, or peroxide with nitric acid were not successful. Total iron in the wastewater discharge from 
TABLE 5. Dissolved Heavy Metal Concentrations in Sample 14-B

Sample Primary Drinking Secondary Drinking

$\begin{array}{cccc}\text { Metal } & \text { Analysis, mg/l } & \text { Water Standard, * mg/l } & \text { Water Standard, * mg/l } \\ \text { As } & 0.27 & 0.05 & \\ \mathrm{Ba} & 0.077 & 1.0 & \\ \mathrm{Cd} & <0.004 & 0.01 & \\ \mathrm{Co} & <0.01 & & \\ \mathrm{Cr} & <0.004 & 0.05 & 1.0 \\ \mathrm{Cu} & <0.004 & & 0.5 \\ \mathrm{Fe} & 0.75 & & 0.3 \\ \mathrm{Mn} & 0.78 & & \\ \mathrm{Mo} & 0.002 & & \\ \mathrm{Ni} & <0.02 & & \\ \mathrm{~Pb} & <0.06 & 0.05 & 5.0 \\ \mathrm{Zn} & 0.049 & & \end{array}$

*Blank designates no standard.

coal perparation plants is currently limited by EPA Effluent Standards to $7 \mathrm{mg} / 1$ for one day, or an average of $3.5 \mathrm{mg} / 1$ for a 30 day period. (EPA, 40 CFR 434). Additional analytical work is needed to establish an accurate iron value. Of the primary standards, only arsenic is exceeded while iron and manganese are exceeded in the secondry standards. Drinking water standards are useful for comparison only to show the relative hazards of a water under inspection. If a wastewater meets drinking water standards, it can certainly be discharged to receiving waters in nearly all instances. If it exceeds drinking water standards by a modest amount, as in the case of arsenic, iron, and manganese above, discharge may still be permitted depending on the volume and quality of the receiving water. Regulatory agencies will determine the allowable discharge levels where no existing effluent standard exists.

The effect of coal on the quality of raw water is best presented by the data in Table 6 . Test 11 in Table 6 was run with 1.2-in. initial average sized coal for 10 hours. The general trend is that pH decreases after coal is added 
TABLE 6. Effect of Coal on the Quality of Raw Water

\begin{tabular}{|c|c|c|c|c|c|c|c|c|c|}
\hline & $\mathrm{pH}$ & $\begin{array}{c}\text { Conductivity } \\
\mu m h \operatorname{mos} / \mathrm{cm} \\
\end{array}$ & $\begin{array}{c}\text { Alkal in ity } \\
(\mathrm{mg} / \mathrm{l}) \\
\text { as } \mathrm{CaCO}_{3} \\
\end{array}$ & $\begin{array}{l}\text { Suspended } \\
\text { Sol ids } \\
(\mathrm{g} / 1) \\
\end{array}$ & $\begin{array}{c}\mathrm{Ca} \\
(\mathrm{mg} / \mathrm{l}) \\
\end{array}$ & $\begin{array}{c}\mathrm{Mg} \\
(\mathrm{mg} / 1) \\
\end{array}$ & $\begin{array}{l}\text { Sulfate } \\
(\mathrm{mig} / 1)\end{array}$ & $\begin{array}{r}c 00 \\
(\operatorname{lng} / 1) \\
\end{array}$ & $\begin{array}{c}00 \mathrm{C} \\
(\mathrm{m} \mathrm{g} / \mathrm{T}) \\
\end{array}$ \\
\hline $\begin{array}{l}\text { Raw Water } \\
\text { B1 ank }\end{array}$ & 7.9 & 240 & 94.4 & 0.105 & 30.8 & 6.52 & 15.8 & $<10$ & $<3$ \\
\hline $\begin{array}{rl}\text { Test } 11 & A \\
B\end{array}$ & $\overline{7} .50$ & $\begin{array}{l}440 \\
425\end{array}$ & $23 \overline{8}$ & $48 \overline{8}$ & $\begin{array}{l}73.8 \\
74.4\end{array}$ & $\begin{array}{l}7.90 \\
7.33\end{array}$ & $7 \overline{6}$ & - & $\overline{12} .2$ \\
\hline
\end{tabular}

to the raw water and generally all the other parameters increase. The decrease in $\mathrm{pH}$ coupled with an increase in alkalinity signifies leaching of buffering agents with possible production of acid by oxidation of reduced sulfur species, e.g., pyrites. The increase in the other parameters is related to the leaching of various materials from the coal.

The effect of the refuse on water quality when tested with coal is best presented by the data in Table 7. Test 11 was run with coal only and Test 12 was run with coal and refuse. The refuse and/or the coal for both tests was of 1.2-in. initial average size particles. Both tests were run for 10 hours. The differences between the test samples for each parameter were considered significant. The decrease of $\mathrm{pH}$ appears to be related to constituents of the refuse that are acidic or are converted to acidic compounds, e.g. sulfates, that lower the pH. The increase of most of the other parameter values relates to the fact that the refuse is harder than the coal. Thus the average coal particle size is reduced by collisions of the refuse and coal as well as the coal and refuse being reduced in size by contact with the pipe wall and pipe joints. A comparison of the hardness of the refuse and coal is given in Appendix B.

The effect of initial average size of the solids on water quality is represented best by the data shown in Table 8 . Test 13 used 1.2-in. average size coal and refuse, and Test 23 used $0.6-i n$. average size coal and refuse. Both tests were run 5 hours. Of the other tests that lend themselves to this discussion (Tests 12 and 24; Tests 14 and 25) three of the four tests generated foam that biased the data. The increases and decreases of the parameter values 
TABLE 7. Effect of Refuse on Water Quality when Tested with Coal

\begin{tabular}{|c|c|c|c|c|c|c|c|c|c|}
\hline & $\mathrm{pH}$ & $\begin{array}{c}\text { Conductivity } \\
\quad \mu m h o s / \mathrm{cm} \\
\end{array}$ & $\begin{array}{c}\text { Alkal inity } \\
(\mathrm{mg} / 1) \\
\text { as } \mathrm{CaCO} \\
\end{array}$ & $\begin{array}{c}\text { Suspended } \\
\text { Sol ids } \\
(\mathrm{g} / 1) \\
\end{array}$ & $\begin{array}{c}\mathrm{Ca} \\
(\mathrm{mg} / 1) \\
\end{array}$ & $\begin{array}{c}\mathrm{Mg} \\
(\mathrm{mg} / \mathrm{l}) \\
\end{array}$ & $\begin{array}{l}\text { Sulfate } \\
(\mathrm{mg} / 1)\end{array}$ & $\begin{array}{c}\mathrm{COD} \\
(\mathrm{mg} / 1) \\
\end{array}$ & $\begin{array}{c}\mathrm{DOC} \\
\text { (mg/T) }\end{array}$ \\
\hline $\begin{array}{rl}\text { Test } 11 & A \\
& B\end{array}$ & $\overline{7} .50$ & $\begin{array}{l}440 \\
425\end{array}$ & $23 \dot{8}$ & $48 \overline{8}$ & $\begin{array}{l}73.8 \\
74.4\end{array}$ & $\begin{array}{l}7.90 \\
7.33\end{array}$ & $7 \overline{6}$ & - & $\overline{12.2}$ \\
\hline Test $12 \mathrm{~A}$ & $\begin{array}{l}7.05 \\
7.05\end{array}$ & $\begin{array}{l}625 \\
660\end{array}$ & $38 \overrightarrow{8}$ & $\begin{array}{l}535 \\
544\end{array}$ & $\begin{array}{l}94.7 \\
92.3\end{array}$ & $\begin{array}{l}12.1 \\
11.7\end{array}$ & $\begin{array}{l}276 \\
328\end{array}$ & 25.7 & $\begin{array}{r}8.8 \\
13.8\end{array}$ \\
\hline
\end{tabular}

TABLE 8. Effect of Initial Average Sized Particles of Coal and Refuse on Water Quality

\begin{tabular}{|c|c|c|c|c|c|c|c|c|c|}
\hline & $\mathrm{pH}$ & $\begin{array}{c}\text { Conductivity } \\
\text { umhos } / \mathrm{cm}\end{array}$ & $\begin{array}{c}\text { Alkalinity } \\
(\mathrm{mg} / 1) \\
\text { as } \mathrm{CaCO}_{3} \\
\end{array}$ & $\begin{array}{l}\text { Suspended } \\
\text { Solids } \\
(\mathrm{g} / 1) \\
\end{array}$ & $\begin{array}{c}\mathrm{Ca} \\
(\mathrm{mg} / 1) \\
\end{array}$ & $\begin{array}{r}\mathrm{Mg} \\
(\mathrm{mg} / 1) \\
\end{array}$ & $\begin{array}{l}\text { Sulfate } \\
(\mathrm{mg} / 1) \\
\end{array}$ & $\begin{array}{r}\text { COD } \\
(\mathrm{mg} / 1) \\
\end{array}$ & $\begin{array}{c}\mathrm{DOC} \\
(\mathrm{mg} / \mathrm{I}) \\
\end{array}$ \\
\hline $\begin{array}{r}\text { Test } 13 \mathrm{~A} \\
\mathrm{~B}\end{array}$ & $\begin{array}{l}7.0 \\
7.05\end{array}$ & $\begin{array}{l}750 \\
670\end{array}$ & $\begin{array}{l}344 \\
333\end{array}$ & $\begin{array}{l}472 \\
479\end{array}$ & $\begin{array}{l}90.5 \\
88.7\end{array}$ & $\begin{array}{l}10.8 \\
10.8\end{array}$ & $35 \overline{0}$ & $\begin{array}{l}502 \\
50^{\prime}\end{array}$ & $\begin{array}{l}160 \\
156\end{array}$ \\
\hline Test $23 \mathrm{~A}$ & $\begin{array}{l}7.2 \\
7.2\end{array}$ & $\begin{array}{l}710 \\
740\end{array}$ & $\begin{array}{l}331 \\
331\end{array}$ & $\begin{array}{l}507 \\
498\end{array}$ & $\begin{array}{l}82.3 \\
91.3\end{array}$ & $\begin{array}{l}11.5 \\
11.7\end{array}$ & $37 \overline{0}$ & $\begin{array}{l}41 \\
39\end{array}$ & $\begin{array}{l}15.8 \\
15.3\end{array}$ \\
\hline
\end{tabular}

are considered insignificant except for $C O D$ and DOC. The decreases in $C O D$ and DOC from Test 13 to Test 23 are unexplainable at this time. The overall conclusion is that the initial starting size of the coal and refuse does not produce a significant difference in effect on water quality except where particle size affects the generation of foam.

The effect of coal concentration on water quality is presented by the data in Table 9. Test 10 was run with 15 vol\% concentration of coal only, and Test 11 was run with 45 vol\% concentration of coal only. Both tests were run with 1.2-in. initial average size coal and for 10 hours. The differences in suspended solids, calcium, sulfate, and dissolved organic carbon are considered significant. Thus it is concluded that these parameters increase with an increase in concentration of coal in the water.

The effect of the time of contact of coal and refuse on water quality is best presented by the data in Table 10 . Test 14 is the 1 -hour test, Test 13 is the 5 -hour test, and Test 12 is the 10-hour test. All these tests were run 
TABLE 9. Effect of Concentration of Solids on Water Quality

\begin{tabular}{|c|c|c|c|c|c|c|c|c|c|}
\hline & $\mathrm{pH}$ & $\begin{array}{c}\text { Conductivity } \\
\text { umhos/cmi }\end{array}$ & $\begin{array}{c}\text { Alkalinity } \\
(\mathrm{mg} / \mathrm{l}) \\
\text { as } \mathrm{CaCO} \\
\end{array}$ & $\begin{array}{l}\text { Suspended } \\
\text { Sol ids } \\
(\mathrm{g} / \mathrm{l})\end{array}$ & $\begin{array}{c}\mathrm{Ca} \\
(\mathrm{mg} / \mathrm{l}) \\
\end{array}$ & $\begin{array}{c}M g \\
(m g / 1) \\
\end{array}$ & $\begin{array}{l}\text { Sulfate } \\
\text { (mg/1) }\end{array}$ & $\begin{array}{r}\mathrm{COD} \\
\text { (mig/1) }\end{array}$ & $\begin{array}{c}D O C \\
(m g / 1) \\
\end{array}$ \\
\hline $\begin{array}{r}\text { Test } 10 \mathrm{~A} \\
\mathrm{~B}\end{array}$ & $\begin{array}{l}7.10 \\
7.40\end{array}$ & $\begin{array}{l}480 \\
520\end{array}$ & $21 \overline{2}$ & $\begin{array}{l}9.50 \\
6.50\end{array}$ & $\begin{array}{l}70.4 \\
65.5\end{array}$ & $\begin{array}{l}7.61 \\
7.49\end{array}$ & $\begin{array}{l}55 \\
32\end{array}$ & - & $\begin{array}{l}5.2 \\
7.8\end{array}$ \\
\hline est $11 \mathrm{~A}$ & $\overline{7} .50$ & $\begin{array}{l}440 \\
425\end{array}$ & $23 \overline{8}$ & $48 \overline{8}$ & $\begin{array}{l}73.8 \\
74.4\end{array}$ & $\begin{array}{l}7.90 \\
7.33\end{array}$ & $\overrightarrow{76}$ & - & $\overline{12} .2$ \\
\hline
\end{tabular}

TABLE 10. Effect of the Time of Contact of Solids in Water on Water Quality

\begin{tabular}{|c|c|c|c|c|c|c|c|c|c|}
\hline & $\mathrm{pH}$ & $\begin{array}{l}\text { Conductivity } \\
\text { pmhos } / \mathrm{cm} \\
\end{array}$ & $\begin{array}{c}\text { Alkal inity } \\
(\mathrm{mg} / 1) \\
\text { as } \mathrm{CaCO} \\
\end{array}$ & $\begin{array}{c}\text { Suspended } \\
\text { Solids } \\
(\mathrm{g} / \mathrm{T}) \\
\end{array}$ & $\begin{array}{r}\mathrm{Ca} \\
\text { (mg/1) } \\
\end{array}$ & $\begin{array}{c}\mathrm{Mg} \\
(\mathrm{mg} / 1) \\
\end{array}$ & $\begin{array}{l}\text { Sulfate } \\
(\mathrm{mg} / 1)\end{array}$ & $\begin{array}{c}\operatorname{COD} \\
(\mathrm{mg} / 1) \\
\end{array}$ & $\begin{array}{c}D O C \\
(\mathrm{mg} / 1) \\
\end{array}$ \\
\hline Test 14 A & $\begin{array}{l}7.0 \\
7.0\end{array}$ & $\begin{array}{l}825 \\
900\end{array}$ & $\begin{array}{l}412 \\
452\end{array}$ & $10 \overline{8}$ & $\begin{array}{l}80.3 \\
79.0\end{array}$ & $\begin{array}{l}7.50 \\
7.50\end{array}$ & $12 \overrightarrow{0}$ & $\begin{array}{l}8,410 \\
8,830\end{array}$ & $\begin{array}{l}2,637 \\
2,647\end{array}$ \\
\hline $\begin{array}{r}\text { Test } 13 \mathrm{~A} \\
\mathrm{~B}\end{array}$ & $\begin{array}{l}7.0 \\
7.05\end{array}$ & $\begin{array}{l}750 \\
670\end{array}$ & $\begin{array}{l}344 \\
333\end{array}$ & $\begin{array}{l}472 \\
479\end{array}$ & $\begin{array}{l}90.5 \\
88.7\end{array}$ & $\begin{array}{l}10.8 \\
10.8\end{array}$ & 350 & $\begin{array}{l}502 \\
502\end{array}$ & $\begin{array}{l}160 \\
156\end{array}$ \\
\hline Test $12 \mathrm{~A}$ & $\begin{array}{l}7.05 \\
7.05\end{array}$ & $\begin{array}{l}625 \\
660\end{array}$ & $38 \overline{8}$ & $\begin{array}{l}535 \\
544\end{array}$ & $\begin{array}{l}94.7 \\
92.3\end{array}$ & $\begin{array}{l}12.1 \\
11.7\end{array}$ & $\begin{array}{l}276 \\
328\end{array}$ & 25.7 & $\begin{array}{r}8.8 \\
13.8\end{array}$ \\
\hline
\end{tabular}

at 45 vol\% concentration of coal and refuse in water and with 1.2-in. initial average size particles. Test 14 generated a foam that is believed to account for at least the very high $C O D$ and $D O C$ values. Considering the foam generated in Test 14, the differences in conductivity, alkalinity, suspended solids, calcium, magnesium, COD, and DOC appear significant. The increase in suspended solids, calcium, and magnesium correlates with the increase in contact time. The decrease in COD and DOC may indicate an adsorption effect similar to that described by Manahan et al. (1980). The adsorption effect is basically that certain organics (such as organic acids) may be readsorbed by the coal as the coal fines increase. Other tests with 0.6-in. and 0.3-in. initial average size coal and refuse could have provided more data for evaluation except foam was generated in two out of three 0.6 -in tests and two out of two 0.3-in. tests. The formation of foam rendered much of the analytical data uncomparable. Thus 
it can only be concluded that the time of contact is directiy related to the increase in suspended solids and may be inversely related to COD and DOC possibly because of an adsorption effect.

The "B" samples from Tests 12, 13, and 14 were tested for settleability of suspended solids by transferring $250 \mathrm{ml}$ of well mixed sample to a graduated cylinder and measuring the settled sludge volume after 1 hour. Settling of suspended solids occurred only for the sample from Test 14, a 1-hour test. The suspended solids in this sample was $33 \%$ of the total volume after 1 hour. The suspended solids concentration in sample $14-B$ was $100 \mathrm{~g} / 7$ compared with 544 and $479 \mathrm{~g} / 1$, respectively, for samples 12-B (a 10-hour test) and 13-B (a 5-hour test). These results indicate that settling may occur without the use of flocculants, however, more rapid settling and thicker sludges are usually possible by using flocculants.

\section{HEAD LOSS RESULTS}

The head loss data obtained during the water quality tests show how the head loss changes with time. With a fresh charge of coal or coal and refuse, the head loss starts out high and drops off rapidly. For the tests run at $22 \mathrm{rpm}(15.5 \mathrm{ft} / \mathrm{sec})$, an equilibrium head loss value was obtained after less than 2 hours in most cases. Figure 14 represents the head loss versus time for Test 11, which was a coal-only test. Figure 15 represents the head loss versus time for Test 12, which was a coal and refuse test. In tests where a foam was generated, the head loss dropped off rapidly but then started to rise steadily if the test lasted long enough. Figure 16 represents head loss versus time for Test 24, which was a coal and refuse test in which foam was generated. In fact the foam generated during Test 24 was one of the thickest foams produced. It is hypothesized that the head loss dropped off rapidly at the start of a test because the sharp corners were broken off the coal and refuse. Figure 17 shows coal before testing at the top and coal after testing at the bottom of the picture. Figure 18 shows refuse before testing at the top and refuse after testing at the bottom of the picture. After the coal and refuse is rounded off, the head loss reaches a rather constant value unless a foam is generated. As a foam is generated, the head loss increases. 


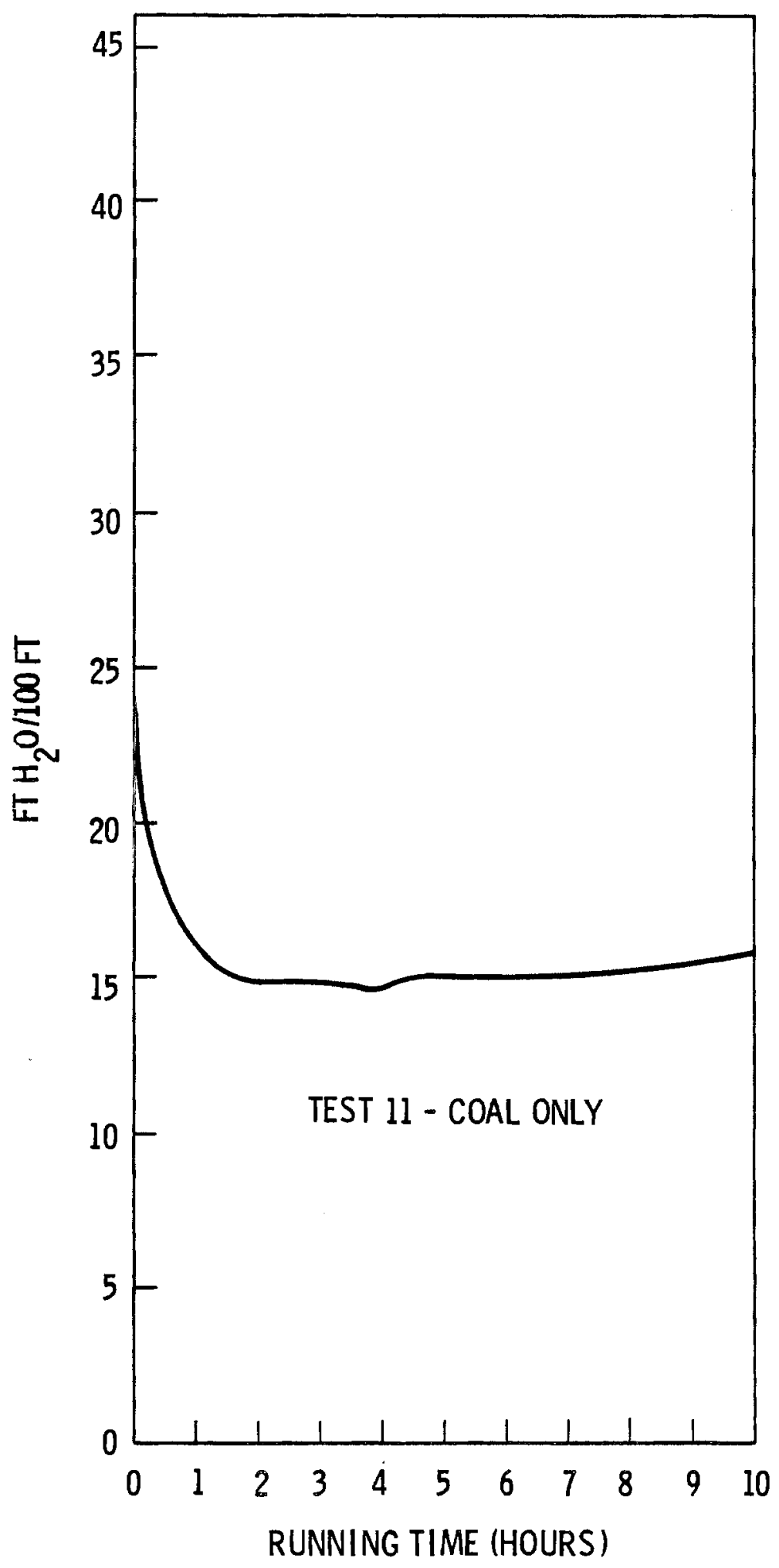

FIGURE 14. Head Loss vs Time During Coal and Refuse Test 


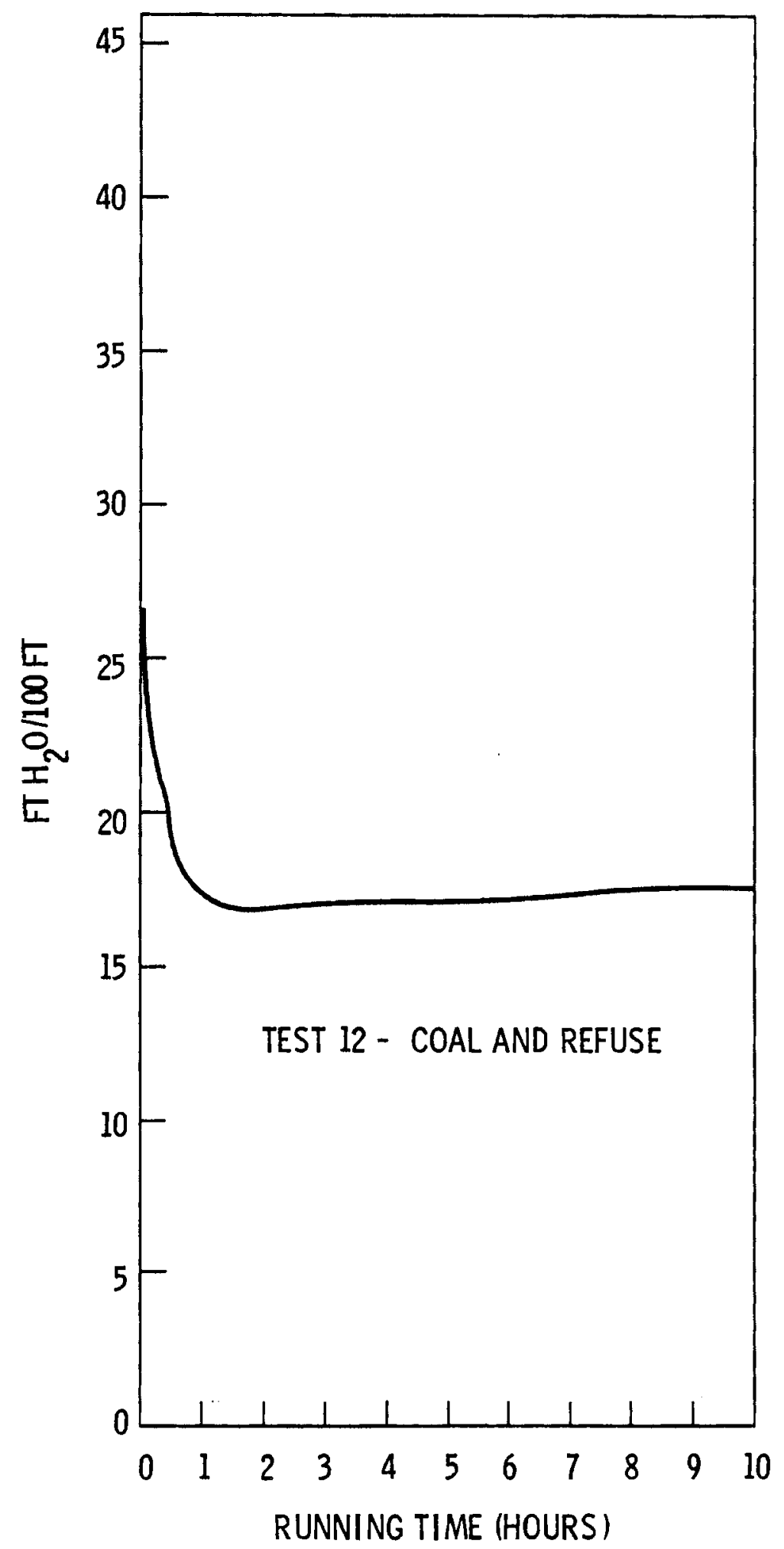

FIGURE 15. Head Loss vs Time During Coal-Only Test 


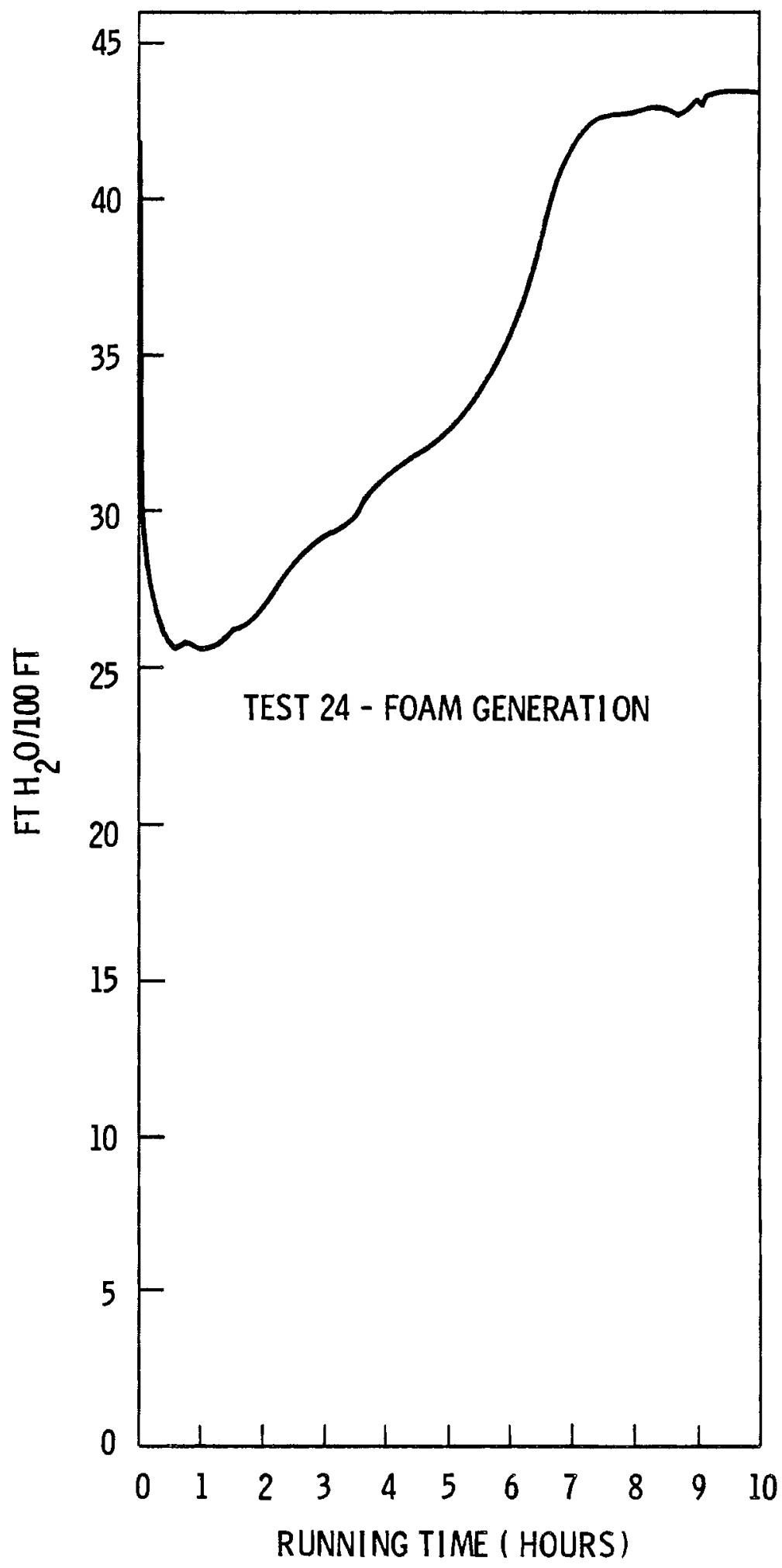

FIGURE 16. Head Loss vs Time During Foam Generation Test 


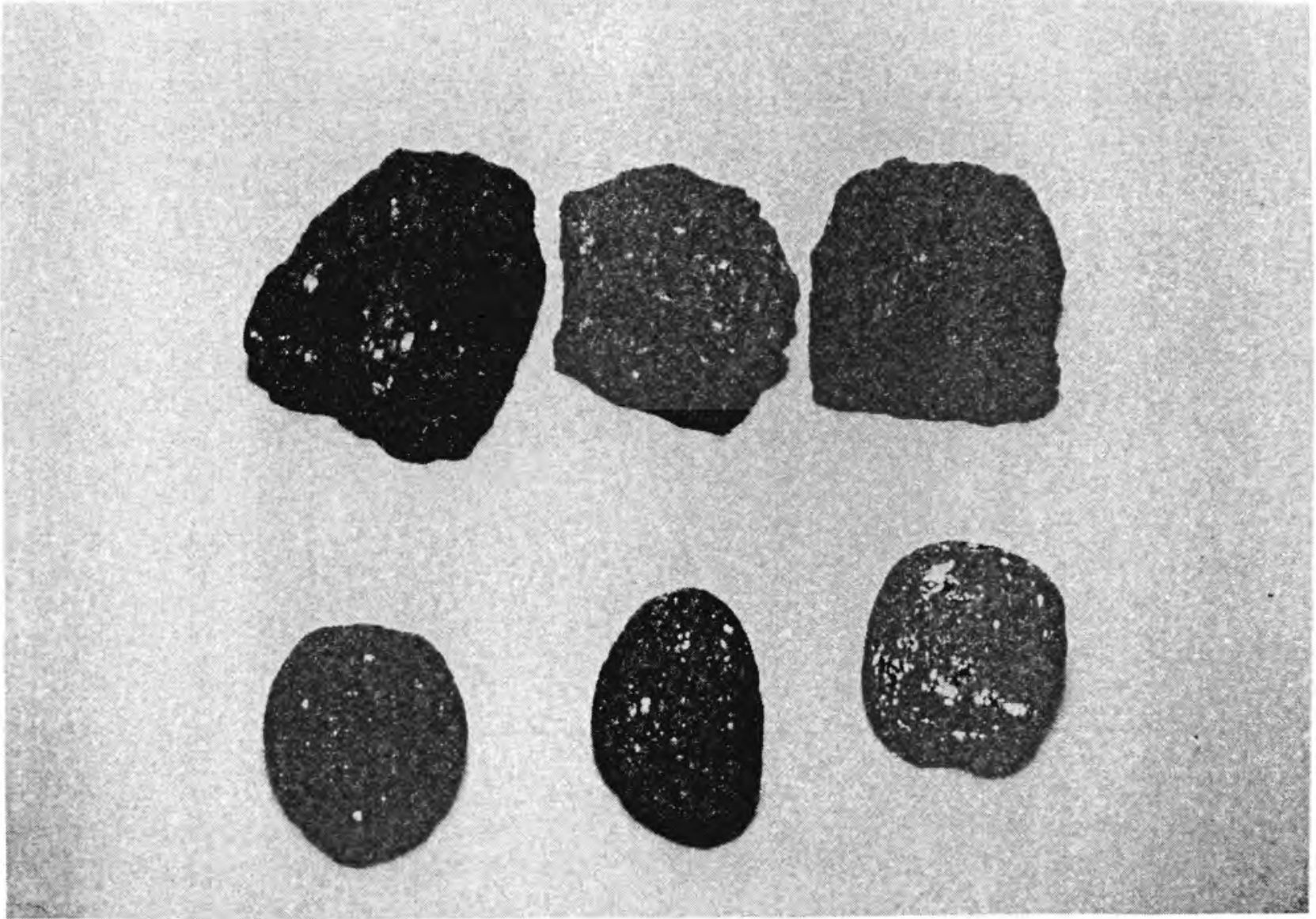

FIGURE 17. Coal Before (top) and After (bottom) Testing 


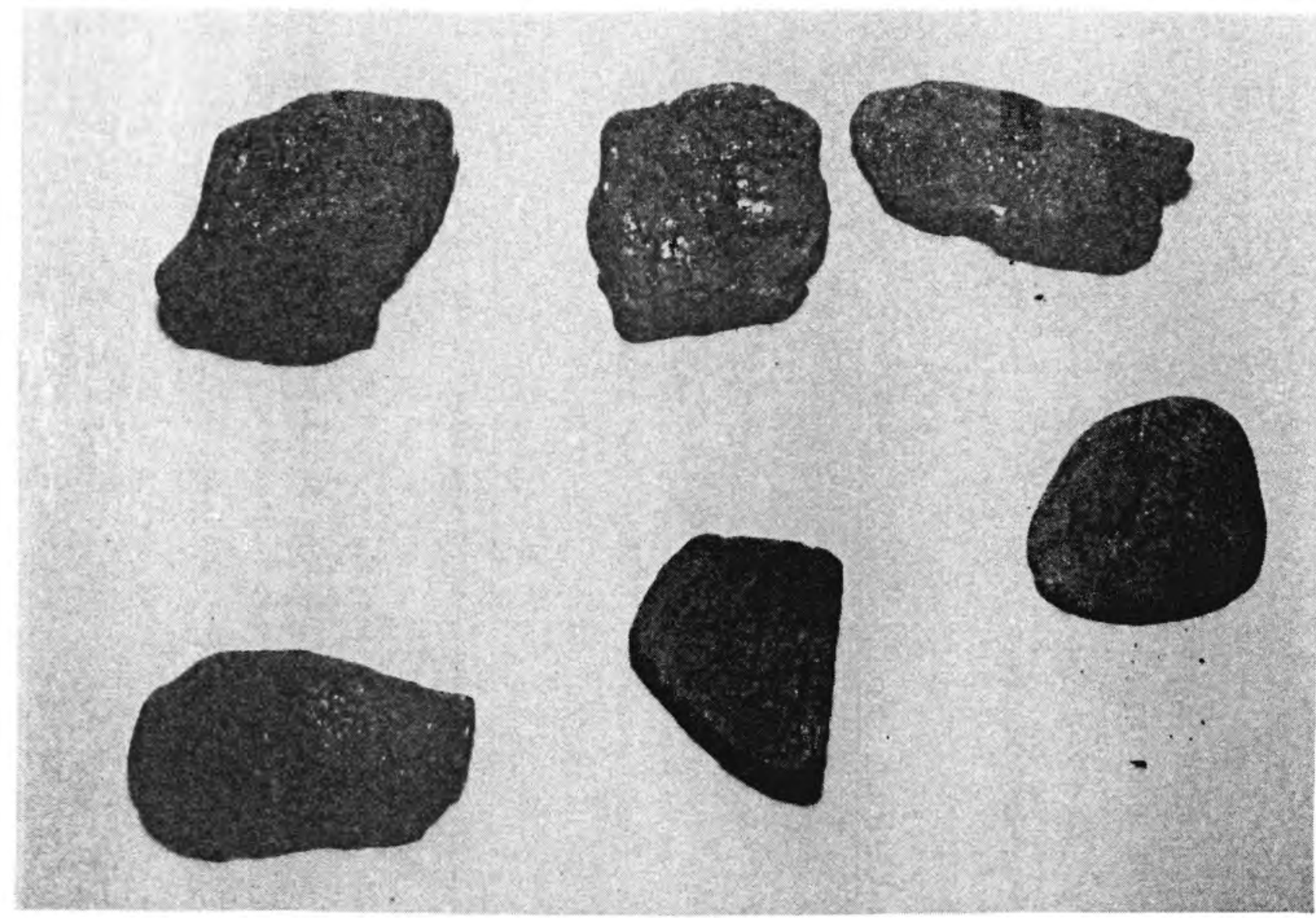

FIGURE 18. Refuse Before (Top) and After (Bottom) Testing 


\section{SIZE DEGRADATION RESULTS}

The following are results of size degradation data obtained during the water quality tests. Because the generation of foam appeared to biase the size degradation data, only tests where no appreciable foam was detected were compared. The size degradation data is plotted as a weight fraction of the total charged to the pipe ring that passed through a given screen opening. Since no two tests being compared both yielded data from which a mass median diameter of particles could be determined, data was compared on just the weight fraction that passed the 5 -mesh screen $(4.0 \mathrm{~mm}$ or $0.16 \mathrm{in.})$. A sample of each screened size of coal or refuse particle larger than 5 mesh was saved from each test. Figure 19 shows a sample of the different sizes of coal particles saved from Test 11 .

The effect of concentration of coal on the size degradation for coal-only tests is presented in Figure 20. Test 10 was run at 45 vol\% concentration of coal in water, and Test 11 was run at 15 vol\% concentration of coal in water. Both tests were run for 10 hours with 1.2-in. initial average size coal. There is only a $2 \%$ difference in fines less than 5 mesh between these two tests.

There is little or no increase in fines less than 5 mesh after 10 hours testing due to an increase in concentration of Pittsburgh Seam coal only in water.

The effect of refuse on the size degradation of coal is presented in Figure 21. Test 11 was a coal-only test and Test 12 was a coal and refuse test. Both tests were run at 45 vol\% concentration of solids in water and for 10 hours. Based on the coal fines less than 5 mesh, the refuse significantly increases the size degradation of coal particles, when compared to a comparable coal-only test. In this particular comparison, the increase in coal fines less than 5 mesh due to testing with refuse was $8 \%$.

The effect of time of testing on the size degradation of coal is presented in Figure 22. Test 13 was a 5-hour test, and Test 12 was a 10-hour test. Both tests were run with 45 v01\% concentration of coal and refuse in water and with 1.2-in. initial average size coa'l and refuse particles. With increasing test time the coal fines less than 5 mesh increase significantly. In this case the amount of coal fines increased $6 \%$. 


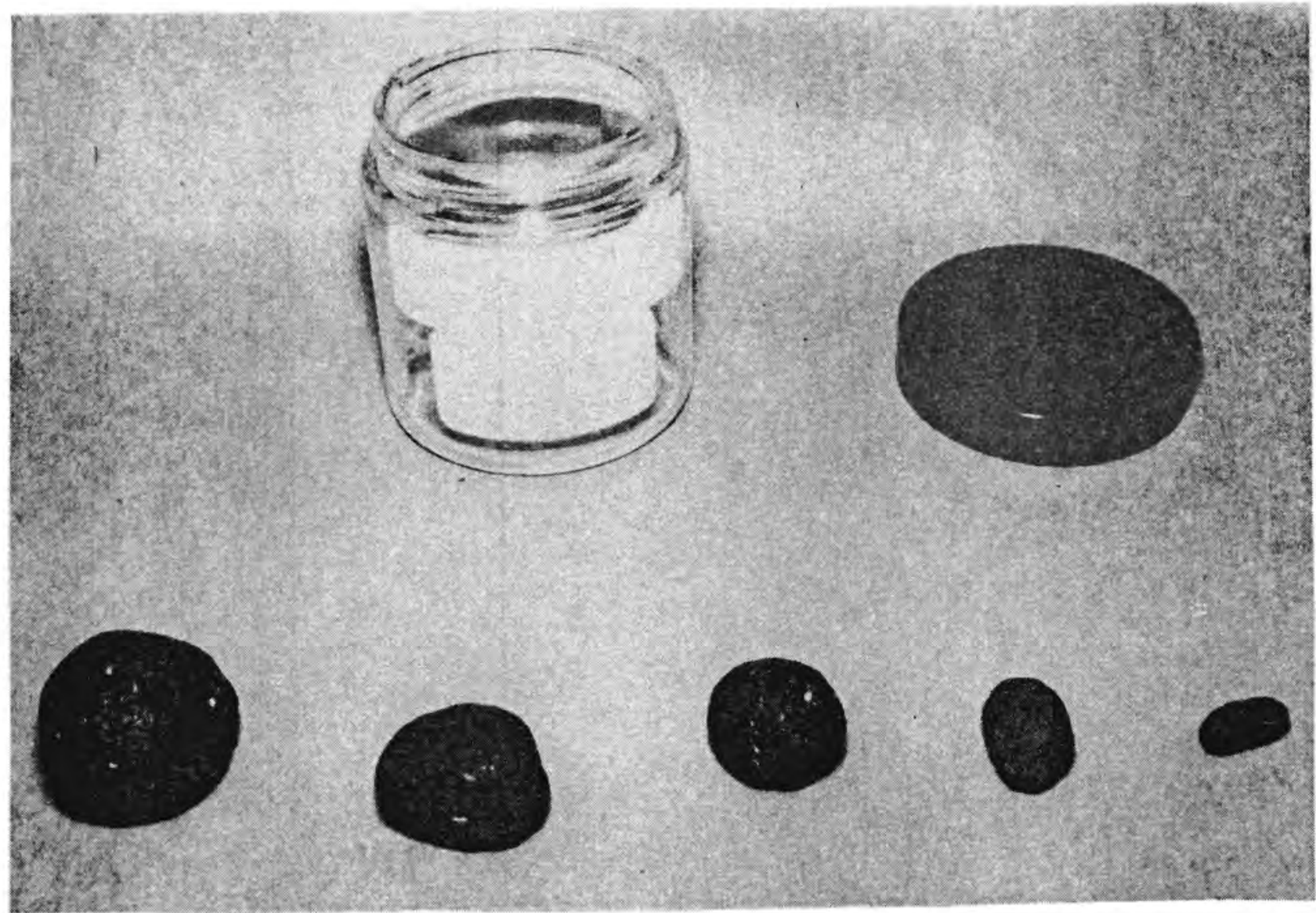

FIGURE 19. Sample of Coal Particles from Test 11 


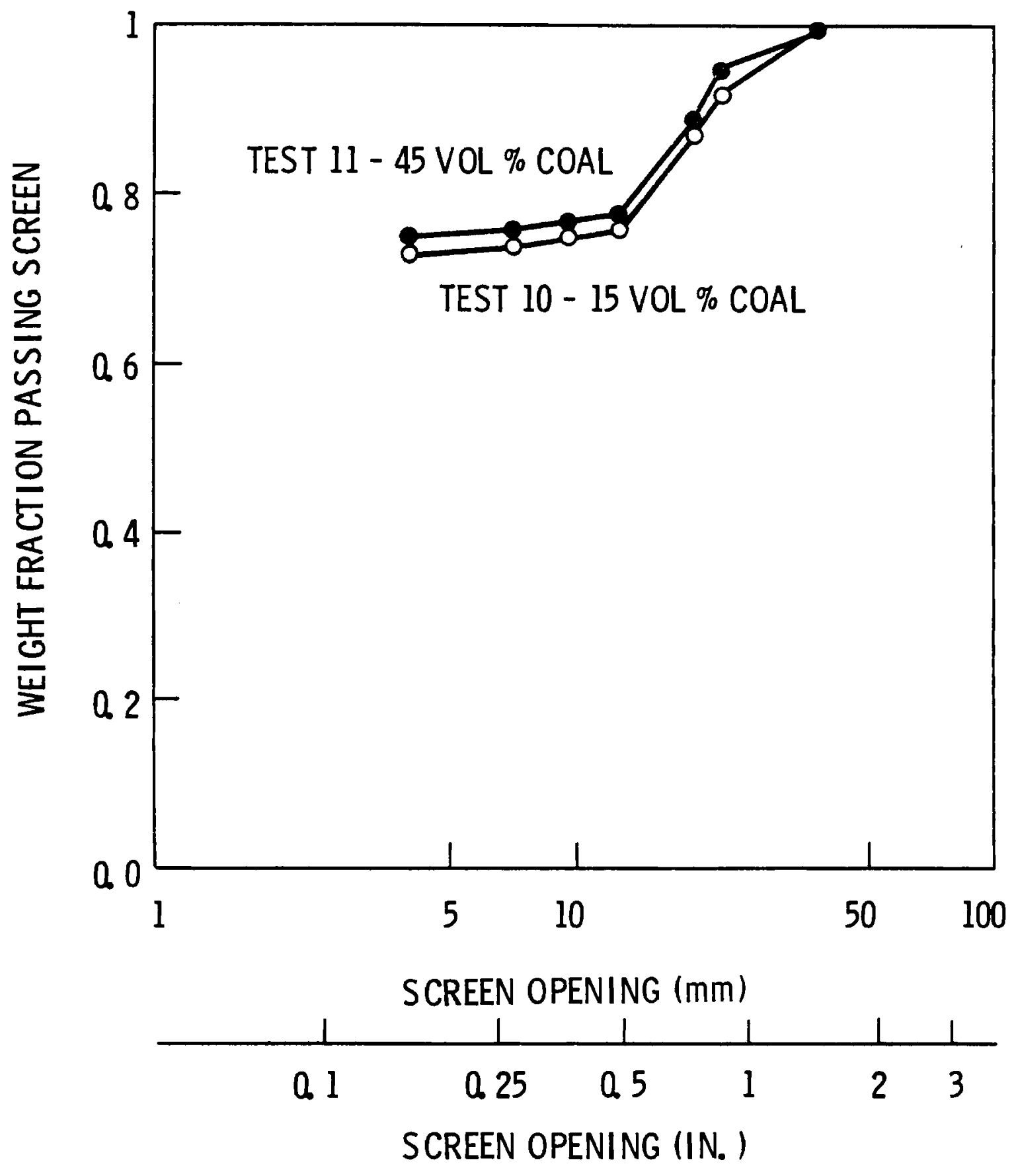

FIGURE 20. Size Degradation for Water Quality Tests 10 and 11 


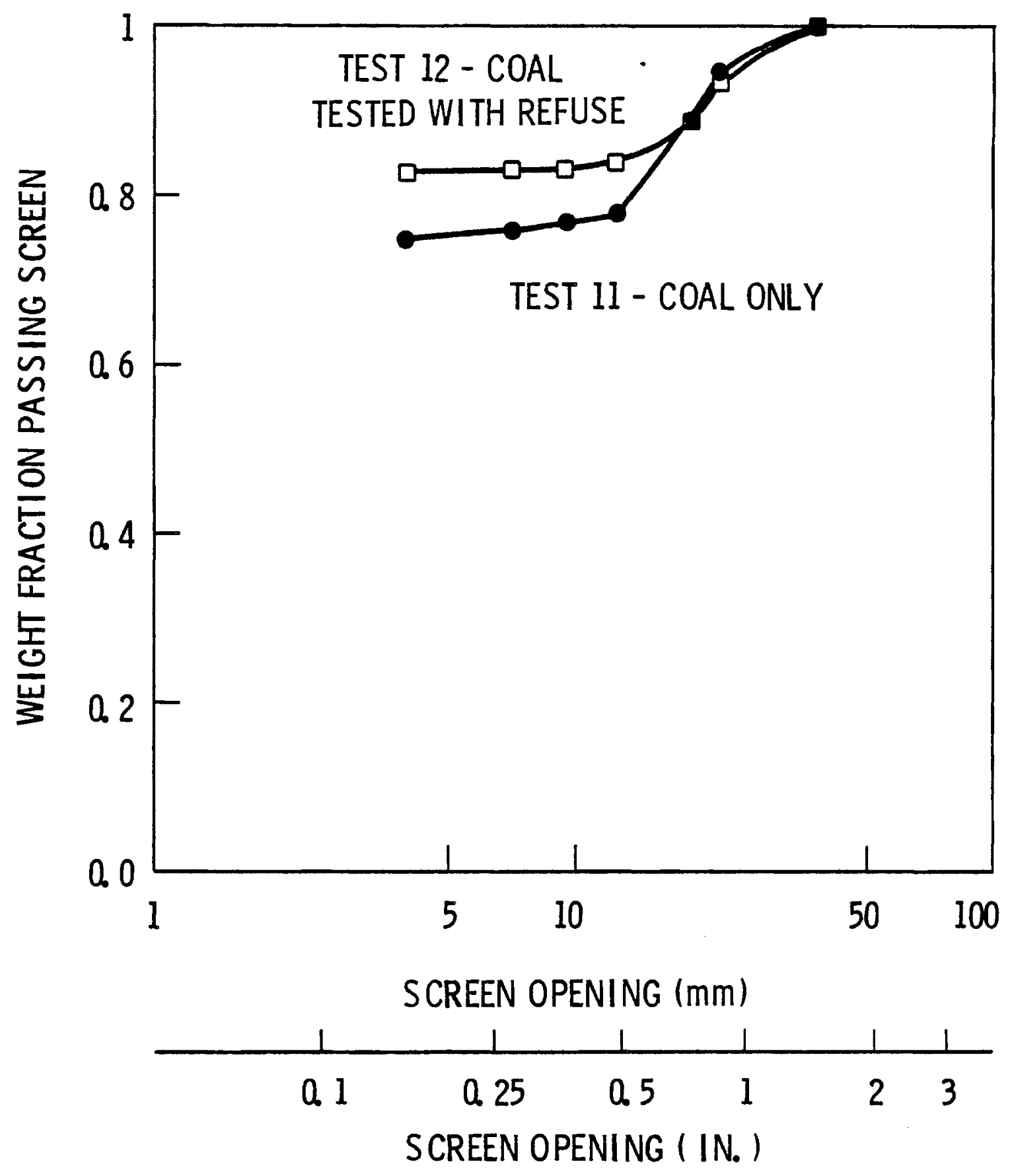

FIGURE 21. Size Degradation for Water Quality Tests 11 and 12 


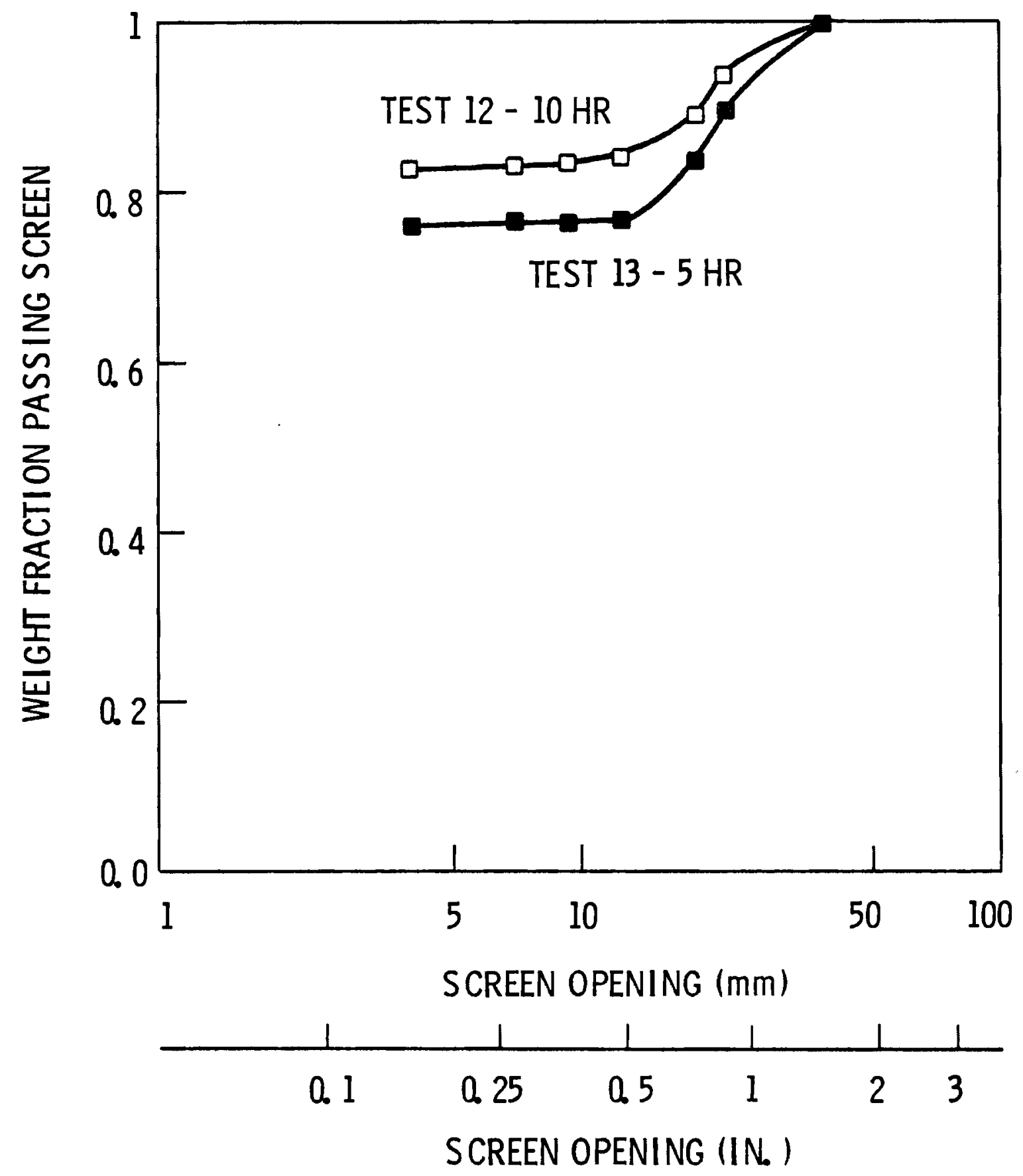

FIGURE 22. Size Degradation for Water Quality Tests 12 and 13 - Coal 
The effect of time of testing on the size degradation of the refuse is presented in Figure 23. Test 12 and 13 have been described in the preceding paragraph. With increasing test time the refuse fines less than 5 mesh also increase. In this case the amount of refuse fines increased $28 \%$.

The effect of initial average size particles on the size degradation of coal is presented in Figure 24 . Test 13 was run with 1.2-in. initial average size coal and refuse particles, and Test 23 was run with 0.6-in. initial average size coal and refuse particles. Both tests were run for 5 hours and with 45 v01\% concentration of coal and refuse in water. With decreasing initial average size particles the coal fines less than 5 mesh decrease for a 5-hour test. In this case the decrease amounted to $11 \%$.

The effect of initial average size particles on the size degradation of refuse is presented in Figure 25 and is the opposite of the coal case. Tests 13 and 23 have been described in the preceding paragraph. With decreasing initial average size particles the refuse fines less than 5 mesh increase for a 5-hour test. In this case the increase amounted to $25 \%$.

A sieve analysis of a special test sample 23-B was performed and the results are given in Table 11 . The test liquid was filtered through a 5 -mesh screen prior to test sample 23-B being taken, thus no particles larger than 5 mesh were contained in test sample 23-B. The entire sample was wet sieved with a 325-mesh (USBS) sieve to remove the very fine material. The solids retained on the sieve were dried and a $50 \mathrm{gram}$ aliquot of the solids was removed for dry sieve analysis (ASTM D-197-30). The minus 325-mesh material constituted $79 \%$ of the total sample, which is characteristic of black-water from a coal preparation plant ( 35 to $80 \%$ minus 325 mesh, tending towards the latter (Aplan and Hogg, 1979). Since the test sample 23-B represented $64 \%$ of the initial coal and refuse by weight, then the minus 325 -mesh material constituted $51 \%$ of the initial coal and refuse by weight $(0.64 \times 0.79=0.51)$. 


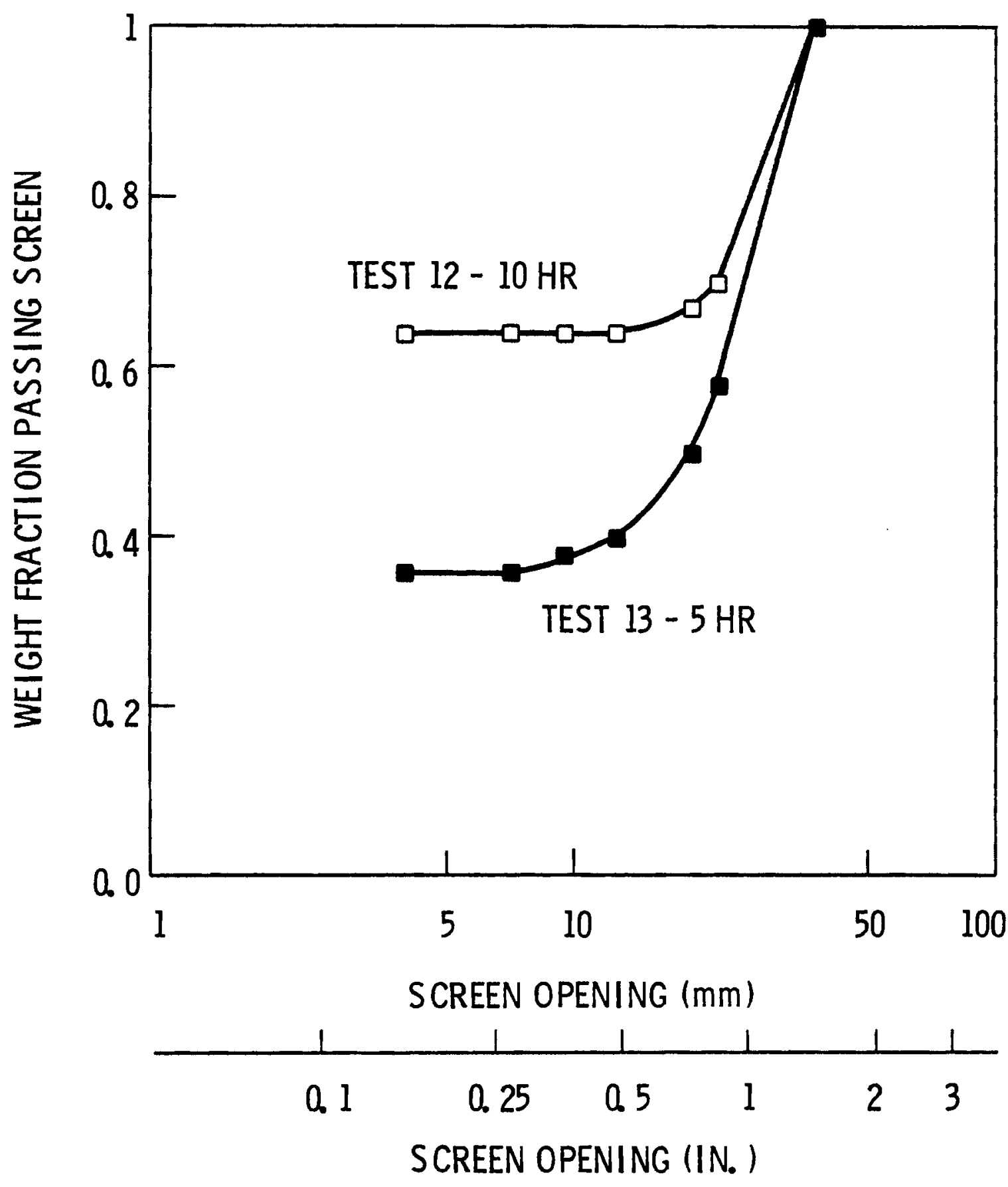

FIGURE 23. Size Degradation for Water Quality Tests 12 and 13 - Refuse 

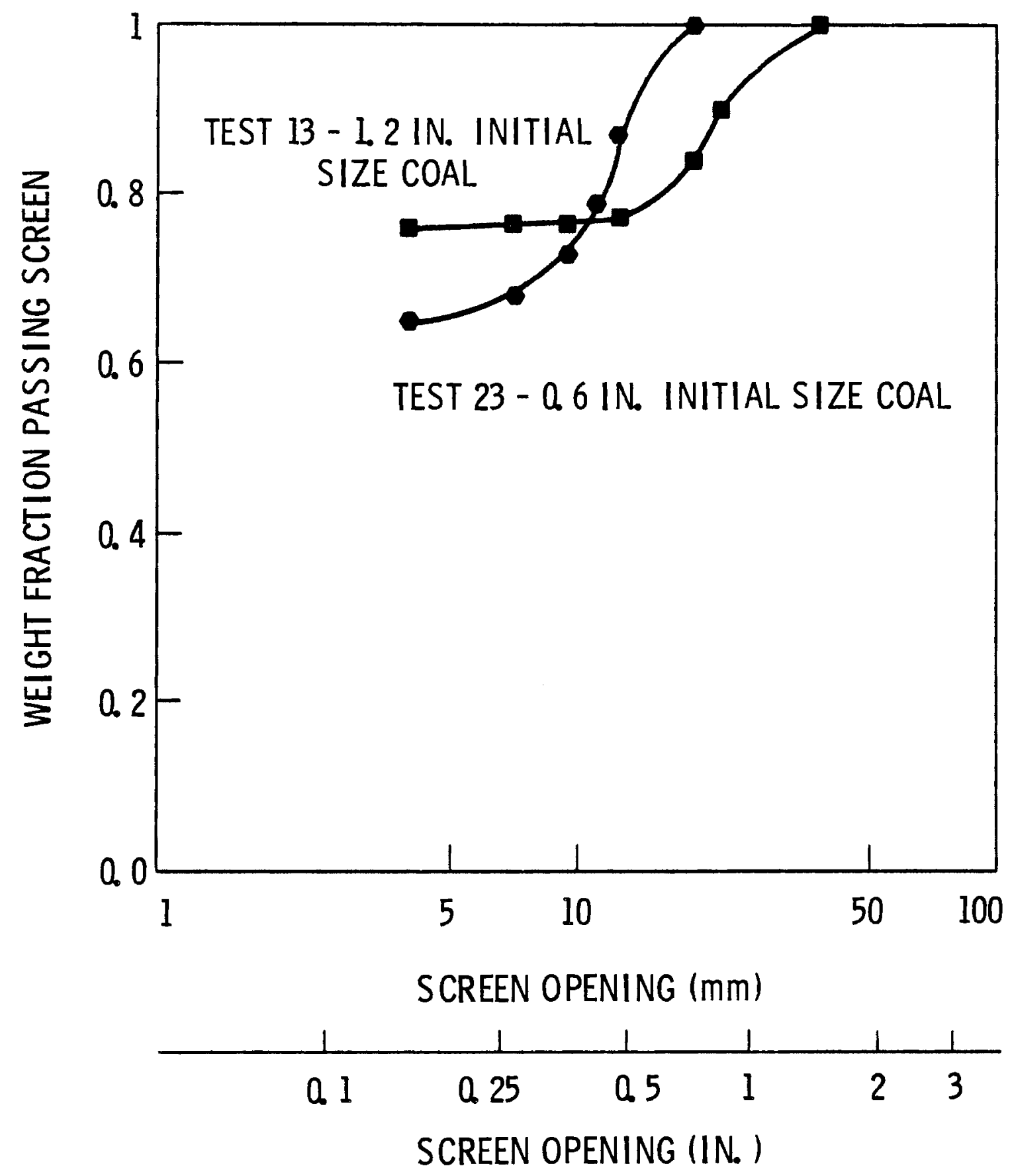

FIGURE 24. Size Degradation for Water Quality Tests 13 and 23 - Coal 


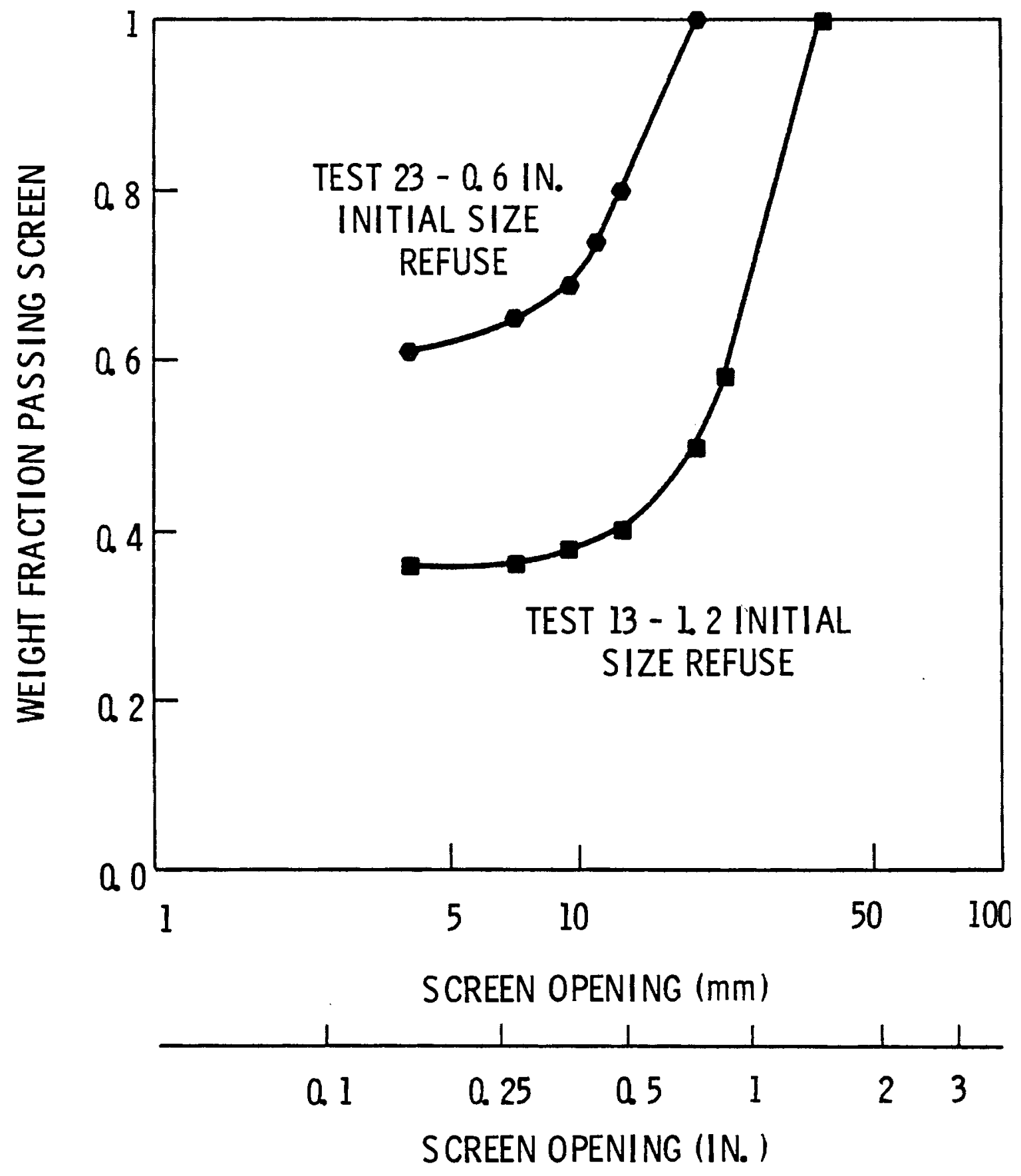

FIGURE 25. Size Degradation for Water Quality Tests 13 and 23 - Refuse 
TABLE 11. Sieve Analysis of Test Sample 23-B

\begin{tabular}{|c|c|}
\hline Sieve Size & $\begin{array}{l}\% \text { Retained or } \\
\text { Sieve or Pan }\end{array}$ \\
\hline 16 & 4.0 \\
\hline 30 & 1.0 \\
\hline 50 & 0.9 \\
\hline 100 & 1.4 \\
\hline 200 & 4.7 \\
\hline 325 & 9.0 \\
\hline Pan* & 79.0 \\
\hline Total & 100.0 \\
\hline
\end{tabular}

*Fines passing the 325 -mesh sieve.

\section{PIPE WEAR RESULTS}

Initial pipe wear data was collected during the water quality tests. This pipe wear data was collected for two reasons; first to examine different methods of determining pipe wear and second to determine if any measurable pipe wear had occurred during the water quality testing.

Three methods of determining pipe wear were used. One method was to measure the thickness of the cover plate insert with a double ball deep throat micrometer. The insert was measured at 26 different marked spots. Another method was to measure the pipe wall thickness using the ultrasonic technique. This technique uses ultrasonic waves to determine the distance of the inner pipe wall from the outer pipe wall. The third method was to weigh a given quarter section of the pipe ring to determine weight loss due to pipe wear.

The results from the micrometer measurements of the cover plate insert indicated an overall decrease in wall thickness of $1.6 \mathrm{mils}$ but with a standard deviation of the measurements of $\pm 3.1 \mathrm{mils}$. Thus apparently due to the precision and accuracy to which the measurements could be made, the results do not give any useable information for any wear that has taken place. 
The results from the ultrasonic measurements indicate an overall average decrease in the pipe wall thickness of $0.75 \mathrm{mils}$. This number takes into account deviations of the individual readings made. This 0.75 mils wear corresponds to passage of 396 tons of Pittsburgh Seam coal and 179 tons of Pittsburgh Seam refuse past any given point in the pipe ring. Based on these numbers, the wear can be expressed as 767 tons of coal and refuse per mil of pipe wall thickness.

The results from weighing a quarter section of the pipe ring before and after certain water quality tests yielded a weight loss of 0.93 pounds. The data obtained by weighing the quarter section of the pipe ring is precise to a standard deviation of 0.05 pounds. Assuming the carbon steel pipe has a density of metal of $0.284 \mathrm{lb} / \mathrm{in}^{3}$., and assuming the wear only takes place in the outer half of the pipe ring, the weight loss of 0.93 corresponds to $2.7 \mathrm{mils}$ of wear. The 0.93 pounds of pipe material corresponds to 1722 tons of Pittsburgh Seam coal and 551 tons of Pittsburgh Seam refuse passing any given point in the pipe ring. Based on these numbers, the wear can be expressed as 842 tons of coal and refuse per mil of pipe wall thickness.

Therefore it is concluded that there was measurable pipe wear during water quality testing but that the exact mils of wall thickness lost is not a precisely known number. 


\section{REFERENCES}

Allen, C. H. 1980. Separate Effects Test Stand for Obtaining Hydrotransport Data. PNL-3468, Pacific Northwest Laboratory, Richland, Washington.

American Public Health Association. 1975. Standard Methods for the Examination of Water and Wastewater. 14th Edition. Washington, D.C.

Aplan, F. F. and R. Hogg. 1979. Characterization of Solid Constituents in Blackwater Effluents from Coal Preparation Plants. U.S. Department of Energy Report No. FE-9002-1.

Environmental Protection Agency. "Effluent Guidelines and Standards for Coal Mining." 40 CFR 434.

Hydraulic Institute. 1979. Hydraulic Institute Engineering Data Book. Cleveland, Ohio.

Manahan, S. E., et al. 1980. Quality and Treatment of Water Involved with Coal Slurry Transport by Pipeline. PB80-160724, National Technical Information Service, Springfield, Virginia.

Schriek, W., et al. 1973. Experimental Studies on the Hydraulic Transport of Coal. Report $V$ of Experimental Studies on Solids Pipelining of Canadian Commodities for the Canadian Transport Commission and the Transportation Development Agency. E73-17, Saskatchewan Research Council.

Trainis, V. V. 1976. C Parametry I Rezhimy Gidravlicheskogo Transportirovaniya UgTya Po Truboprovodam. (Translated by the U.S. Bureau of Mines. 1976. Parameters and Regimes for the Hydraulic Transportation of Coal by Pipelines. Washington, DC) PB280986, National Technical Information Service, Springfield, Virginia.

Worster, R. C., and D. F. Denny. 1955. "Hydraulic Transport of Solid Materials in Pipes." Inst. Mech. Engr. Proc. 169:563-568. 


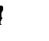


APPENDIX A

DEFINITIONS AND SIGNIFICANCE OF WATER QUALITY PARAMETERS 
APPENDIX A

\section{DEFINITIONS AND SIGNIFICANCE OF WATER QUALITY PARAMETERS}

1. ph. $\mathrm{pH}$ is the negative logarithm of the effective hydrogen ion concentration or hydrogen-ion activity in gram equivalent per liter used in expressing both acidity and alkalinity on a scale whose values run from 0 to 14 with 7 representing neutrality, numbers less than 7 increasing acidity, and numbers greater than 7 increasing alkalinity. Regulatory agencies usually limit the $\mathrm{pH}$ of wastewater discharges to surface water to between $\mathrm{pH} 6$ and 9 .

2. Conductivity. Conductivity is a measure of the dissolved electrolyte in the wastewater and is usually reported as $\mu$ mhos $/ \mathrm{cm}$. Potable waters in the United States generally range from 50 to $1500 \mu \mathrm{mhos} / \mathrm{cm}$. Waters exceeding 2200 umhos/cm are generally not suitable for irrigation.

3. Alkalinity. Alkalinity is a measure of the concentration of basic substances such as bicarbonates, carbonates, and hydroxides in a wastewater. Total alkalinity indicates the amount of acid that would be required to adjust the $\mathrm{pH}$ to a level typically between 3.7 and 4.8 (Methyl Red end point). A high alkalinity at near neutral pH usually indicates high bicarbonate alkalinity or the presence of another buffering agent. Phenolpthalien alkalinity for wastewaters at $\mathrm{pH}$ levels above $\mathrm{pH} 8.3 \mathrm{can}$ be used to calculate the amount of acid required to bring the $\mathrm{pH}$ down to about 8.3. Alkalinity is typically reported as $\mathrm{mg} / 7 \mathrm{CaCO}_{3}$, a milliequivalent of $\mathrm{CaCO}_{3}$ being $50 \mathrm{mg}$.

4. Suspended Solids. Suspended Solids as presented in this report are the amount of solids filtered from an aliquot of a well mixed sample and dried to constant weight at $103^{\circ} \mathrm{C}$. EPA Effluent Standards call for limits on suspended solids: $70 \mathrm{mg} / 1$ for one day and an average of $35 \mathrm{mg} / 1$ for 30 days. 
5. Calcium ( $\mathrm{Ca}$ ) and Magnesium (Mg). These metals are determined by atomic absorption spectroscopy with a flame unit. High concentrations indicate dissolution of salts of these ions $\left(\mathrm{SO}_{4}{ }^{-}\right.$and $\left.\mathrm{Cl}^{-}\right)$or dissolution of limestone by acidic components in the waste. $\mathrm{Ca}^{+2}$ and $\mathrm{Mg}^{+2}$ contribute to hardness in water.

6. Sulfate $\left(\mathrm{SO}_{4}{ }^{2}\right)$. High sulfate concentrations indicate potential oxidation of pyritic matter (metallic sulfide compounds, especially iron disulfide) in the coal or dissolution of sulfate salts (e.g., $\mathrm{CaSO}_{4} \cdot 2 \mathrm{H}_{2} \mathrm{O}$ or gypsum). oxidation of pyrites is accompanied by acid formation in oxygenated waters due to oxidation of $\mathrm{Fe}^{+2}$ to $\mathrm{Fe}^{+3}$, the salts of which hydrolyze to release acids.

7. Chemical Oxygen Demand (COD). Chemical oxygen demand is a measure of the oxygen equivalent of substances in a wastewater that are susceptable to oxidation by dichromate in a strong sulfuric acid solution at boiling temperatures (under reflux) for two hours. It is a rough indicator of the amount of carbonaceous matter and of the ultimate oxygen demand that the wastewater will place on a receiving stream. COD in coal pile runoff and coal preparation wastewaters is not viewed with great concern.

8. Dissolved Organic Carbon (DOC). Dissolved organic carbon is determined by filtering some wastewater and then taking the filtered liquid and measuring the amount of $\mathrm{CO}_{2}$ given off after combustion of the filtered sample at $900^{\circ} \mathrm{C}$. Inorganic carbon as carbonate is removed from the filtered sample by acidification and air sparging prior to injection into the furnace of the analyzer. High DOC levels indicate potential problems with either oxygen demand or toxic organic substances.

9. Chloride $\left(\mathrm{Cl}^{-}\right)$and Fluoride $\left(\mathrm{F}^{-}\right)$ions. These would result from dissolution of their respective salts. Chloride is usually not a problem at levels below $300 \mathrm{mg} / 1$. Fluoride can cause problems above $2 \mathrm{mg} / 1$ in drinking water. These ions are determined by ion chromatography. 
APPENDIX B

HARDNESS COMPARISON OF PITTSBURGH SEAM COAL AND REFUSE 


\section{HARDNESS COMPARISON OF PITTSBURGH SEAM COAL AND REFUSE \\ by \\ Randal1 E. Brown \\ Registered Geologist \\ California Certificate 525 \\ Oregon Certificate G-385}

MOH'S SCALE OF HARDNESS

The hardness of minerals is most commonly measured by Moh's scale of hardness. This is universally stated in terms of the following minerals:

\begin{tabular}{|c|c|c|c|}
\hline Hardness & Mineral & Hardness & Mineral \\
\hline 1. & Talc & 6. & Orthoclase \\
\hline 2. & Gypsum & 7. & Quartz \\
\hline 3. & Calcite & 8. & Topaz \\
\hline 4. & Fluorite & 9. & Corundum \\
\hline 5. & Apatite & 10. & Diamond \\
\hline
\end{tabular}

Talc, with a hardness of 1 , has a greasy feel, common to comparably soft minerals. Gypsum, with a hardness of 2 , is easily scratched with a finger nail (hardness about 2-1/2). Calcite is scratched easily by a knife, in turn scratches a finger nail. Fluorite is scratched by a knife fairly readily, apatite with some difficulty. Orthoclase is barely scratched by a knife but distinctly by a file. Orthoclase will, in turn, scratch ordinary glass.

Quartz scratches most glass and is little touched by a file.

Moh's scale of hardness is not a linear scale although portions approach linearity. Thus, the difference between corundum and diamond ( 9 to 10 ) is greater than the difference between talc and corundum ( 1 to 9 ). 
The lack of linearity is shown in Figure B.1, which shows hardness as determined by the use of sclerometers and comparable methods. The results of different types of hardness tests on Moh's minerals differ significantly from each other, as shown by the three curves.

The property of hardness is only partly understood, and absolute hardness cannot be measured accurately, although standardized tests give reproducible results. The difficulty in measuring "resistance to abrasion" is demonstrated by an automobile tire that may roll for tens of thousands of miles after a steel wheel is completely worn out.

Absolute hardness is depending upon many factors, the most obvious of which include:

1. resilience (the automobile tire)

2. chemical composition

3. crystal faces

4. cleavage and fracture characteristics

5. degree of weathering or alteration.

The hardness of substances other than minerals that have a relatively uniform chemical composition and a characteristic crystal form is even more complex. Thus, rocks are composed of minerals or other rocks each with its own hardness. A quartz sandstone, for instance, may be cemented by calcite. It may appear relatively soft (3). In reality the individual mineral grains may tear out of the cement. Similarly, some rocks contain minerals or other rocks that may be crushed, with the cementing agents or other constituents being unaffected.

\section{THE PITTSBURGH COAL SEAM SLATE}

Slate from the Pittsburgh coal seam exhibits somewhat variable degrees of hardness. Its overall Moh's hardness is 3 (that of calcite). However, variable amounts of organic carbon (a carbonaceous slate) decreases the hardness to about 2-1/2 (can barely be scratched by a fingernai1). The sample, in addition, may or may not be a truly representative sample. 


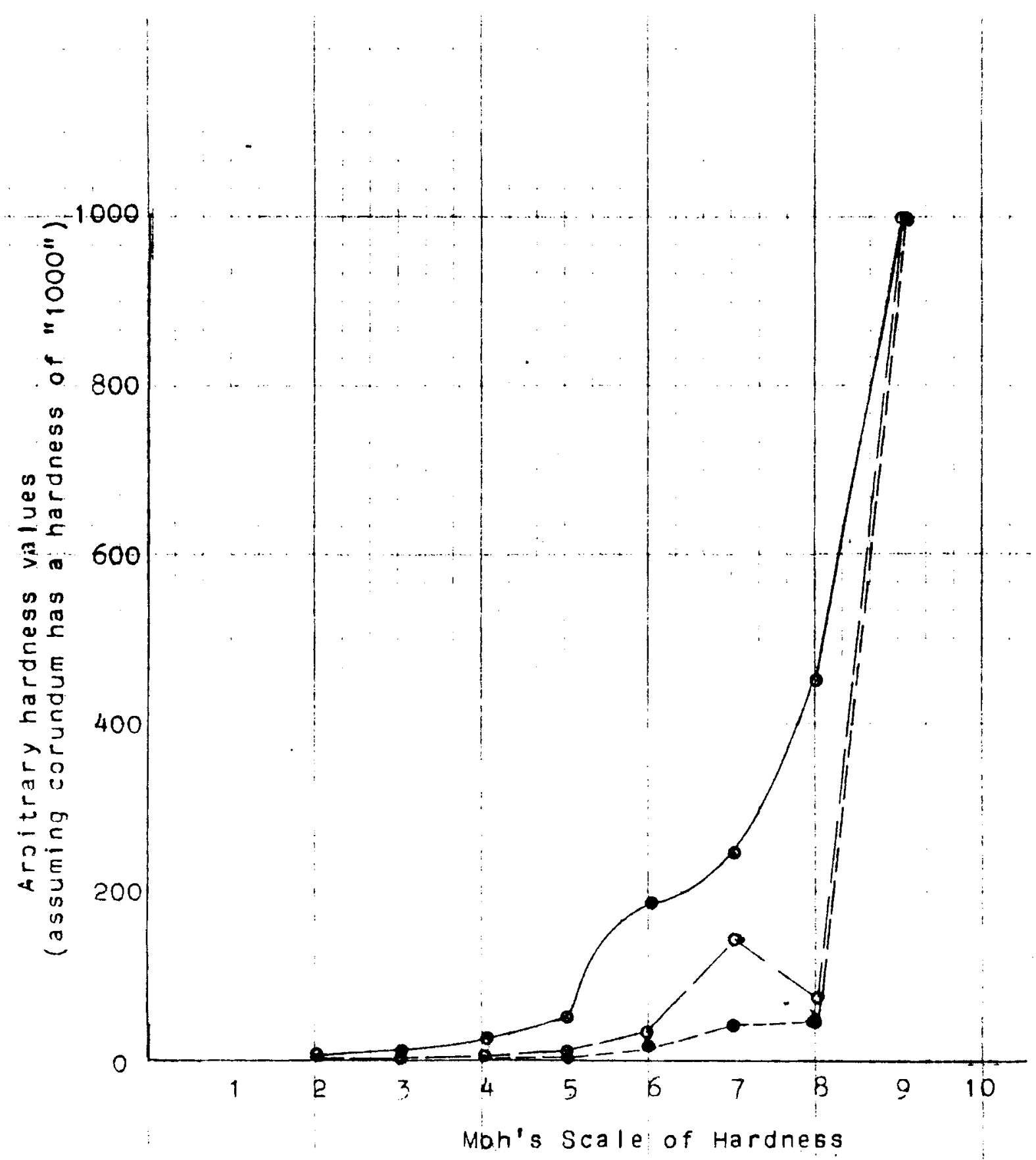

FIGURE B.1. Graph Showing the Absolute Hardness of the Moh Minerals, as Variously Determined. (From WE Ford, Danas Textbook of Mineralogy, 4 th edition, (1932)

Slate from the Pittsburgh coal seam is a slightly metamorphosed shale. Hence it is a naturally laminated sediment in which the initial bedding and an 
induced secondary cleavage and fissility are present. These characteristics were exhibited by the sample. The degree of metamorphism is not precisely known but probably has not progressed to the point where recrystallization of the constituent minerals has occurred. A thin section of the rock and examination with a petrographic microscope would be necessary to determine that.

The slate consists probably of clay- and silt-sized particles of sediment. Clastic sediments constitute a large part of the rock, including quartz, feldspars and trace amounts of a host of minerals. Clay minerals also are prominent, but the precise clay minerals are uncertain. Owing to the micron-sized nature of the particles, the use of petrographic microscopes, supplemented by analytical methods, are necessary to fully identify the composition of the slate.

The chemical composition of shales and slates commonly lies within a fairly narrow range, but variations can and do occur, both from bed to bed and from site to site in the same bed, owing to differences in the source material and to subsequent changes such as diagenesis, cementation, weathering and so on. The overall composition, as well as the clay mineralogy easily may be important in assessing possible reactions between the slurry liquids and slate, or with other materials in the slurry. Hence I urge that some study of the slate mineralogy be undertaken. Perhaps data already are available in published reports on the coal seam.

THE PITTSBURGH COAL

The Pittsburgh coal clearly is slightly softer than the shale. It has a Moh's hardness of 2.5 to nearly 3. Thus the slate scratches the coal, and the coal does not scratch the slate. The coal is, however, brittle and will readily pulverize, the slate has a higher tenacity and will tend to break into flakes along the bedding or induced parting. 
PNL-4011

$U C-90 b$

\section{DISTRIBUT ION}

No. of

Copies

OFFS ITE

A. A. Churm

DOE Patent Division

9800 S. Cass Ave.

Argonne, IL 60439

DOE Office of Fossil Fuels

Washington, DC 20545

Anthony J. Miscoe

Supervisory Mechanical Engineer

DOE Pittsburgh $M$ ining Operations Center

4800 Forbes Ave.

Pittsburgh, PA 15213

Eugene Palowitch.

Director

DOE Pittsburgh Mining Operations Center

4800 Forbes Ave.

Pittsburgh, PA 15213

C. Goode

DOE Pittsburgh Mining Operations Center

4800 Forbes Ave.

Pittsburgh, PA 15213

William Schmidt

Director

Office of Coal Mining

Division of Fossil Fuel Extraction

U.S. Department of Energy, D-107

Washington, DC 20545

27 DOE Technical Information Center
No. of

Copies

ONS ITE

DOE Richland Operations Office

H. E. Ransom

66

Pacific Northwest Laboratory

C. H. Allen

G. B. Dudder

W. I. Ender 1 in (10)

L. L. Eyler

A. J. Haverfield

G. H. Lyon

W. V. Loscutoff

M. J. Mason

S. W. Matsumoto

B. W. Mercer

T. B. Powers (37)

E. B. Schwenk

L. R. Shotwell

A. M. Sutey

Publishing Information SH (2)

Technical Information (5) 
$\checkmark$ 